DANMARKS GEOLOGISKE UNDERS $\emptyset$ GELSE

II. Række. Nr. 101

- Geological Survey of Denmark. II. Series. No. 101

\title{
Further contributions to the knowledge of the Palaeozoic of Slagelse no. 1, Western Sealand
}

BY

Chr. Poulsen

DANSK SAMMENDRAG

Yderligere bidrag til kendskabet til palcozoikum

$i$ Slagelse $n r .1$, Vestsjalland

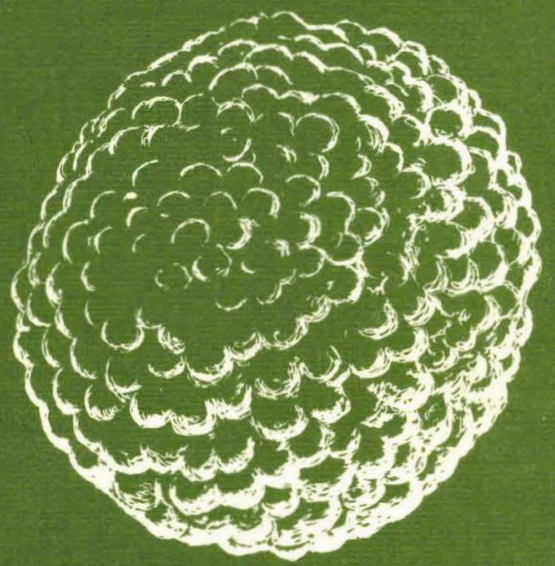


Danmarks Geologiske Undersøgelse . II. Række. Nr. 101

Geological Survey of Denmark . II. Series. No. 101

\section{Further contributions to the knowledge of the Palaeozoic of Slagelse no. 1, Western Sealand}

By

Chr. Poulsen

Dansk sammendrag:

Yderligere bidrag til kendskabet til palæozoikum

i Slagelse nr. 1, Vestsjælland

I kommission hos C. A. Reitzels Forlag

København 1974 
D. G. U. II. rk. nr. 101

er sat med Linotype Times

og trykt i 1200 eksemplarer

hos Andelsbogtrykkeriet i Odense.

Klicheerne er fremstillet af

Tutein \& Koch og fototavlerne af

F. Hendriksen's Eftf.

Bogen er trykt på ekstraglittet 262, $125 \mathrm{~g}$

og plancherne på Top-Cote 106, $120 \mathrm{~g}$

fra a/s De forenede Papirfabrikker.

ISBN 8742106346

With 15 plates

Date of publication: 1974-06-17 


\section{Contents}

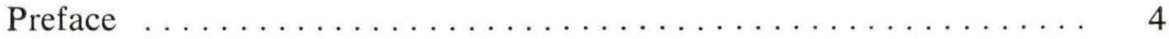

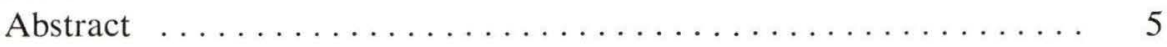

I. The Alum Shale and the Silurian Rocks and fossils ........ 6

The black Shale ....................... 7

The grey Shale and Siltstone Series $\ldots \ldots \ldots \ldots \ldots \ldots \ldots \ldots .6$

The stratigraphic Position of the Silurian at Slagelse ....... 8

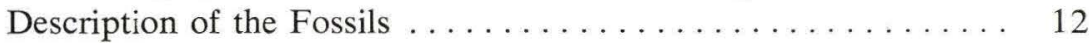

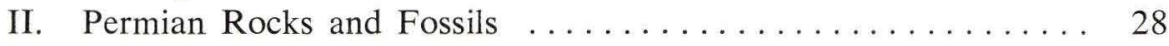

The dark red, silty, non calcareous Claystone .......... 28

The grey Dolomite and dark grey, thinly laminated Shale ...... 28

Description of the Fossils ..................... 29

III. Outline of Palaeogeography and geological Development ...... 34

IV. Dansk Sammendrag .......................... 39

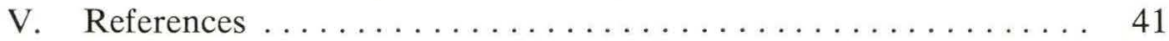

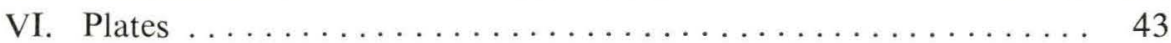




\section{Preface}

In a report of 1964, "Deep Tests in Denmark 1935-1959" (Geological

Survey of Denmark, 3. ser. no. 36) Professor Theodor Sorgenfrei, Ph. D., of The Technical High School of Denmark and Arne Buch, M. Sc., of the Geological Survey of Denmark published brief descriptions of material originating from a considerable number of boreholes in Denmark and presented an important outline of the Pre-Pleistocene stratigraphy of the country. In a locality $4.4 \mathrm{~km}$. SSE of Slagelse City and $700 \mathrm{~m}$. N. of Harrested village, referred to as Slagelse no. 1, drilling penetrated to a depth of $2973.30 \mathrm{~m}$. below the ground. The lowermost $390 \mathrm{~m}$. of the strata were referred to the Lower Palaeozoic.

The writer is much indebted to the Director of The Geological Survey of Denmark, Dr. O. Berthelsen, who placed the material from Slagelse at his disposal for study and publication. Special thanks are due to Dr. L. Banke Rasmussen and Arne Buch, M. Sc., of The Geological Survey of Denmark for important supplementary information, and to Finn Bertelsen, M.Sc., of the same institution for making slides for palynological study. Most figures in the plates accompanying the present paper are photographs taken by the writer; the prints have been made with great care and ability by $\mathrm{Mr}$. P. Nielsen of The Mineralogical-Geological Institutes of the University of Copenhagen. The polished sections of framboidal pyrite and the photographs taken by means of scanning electron microscope were made respectively by Dr. H. Urban and Mrs. A. Nørgaard-Jensen of The Mineralogical-Geological Institutes of the University of Copenhagen. The writer is also indebted to Michal Robson, Cand. Sc., who has corrected his English. Last but not least the writer makes grateful acknowledgement of the financial support which has been extended to him in this research by the Carlsberg Foundation. 


\section{Abstract}

The material described and discussed in the present paper originates from a deep borehole near Slagelse on western Sealand. The lowermost strata have been referred to the Lower Cambrian (Sorgenfrei \& Buch 1964 and C. Poulsen 1969). The present paper deals with the succession of strata between the Lower Cambrian and the Upper Permian evaporite series. The sediments in question are: Alum shale (lowermost part possibly Middle Cambrian and uppermost part possibly basal Ordovician), shales and siltstones with Lower Silurian graptolites (Table 2, p. 11), red, silty claystone (Rotliegendes?), and finally grey dolomite and dark grey, thinly laminated shale with Upper Permian gymnosperm pollen and numerous remains of a vigorous vegetation of hepatics.

The description and discussion of the Silurian fossils embrace trace fossils, brachiopods, eurypterids, asteroids, graptolites (e. g. two new species of Dictyonema and a new species of Monograptus), and finally a few vertebrate scales. A study of numerous Silurian specimens of framboidal pyrite resulted in several new observations; the framboids may be explained as primitive pyritized algae.

The Upper Permian microflora contains a very predominant new species of Lueckisporites; the macroflora consists exclusively of new species of hepatics referable to Jungermannites and Gessella n. g.

The Palaeozoic palaeogeography and geological development of the Slagelse region is discussed in connection with a comparison with sections of some other localities. 


\section{The alum shale and the Silurian rocks and fossils}

As mentioned in the preface, Sorgenfrei \& Buch (1964) referred about $390 \mathrm{~m}$. of the penetrated strata at Slagelse to the Lower Palaeozoic. The lowermost $28 \mathrm{~m}$. were referred to the Lower Cambrian by the present writer (1969). The remaining part of the Lower Palaeozoic has been characterized by Sorgenfrei \& Buch as follows:

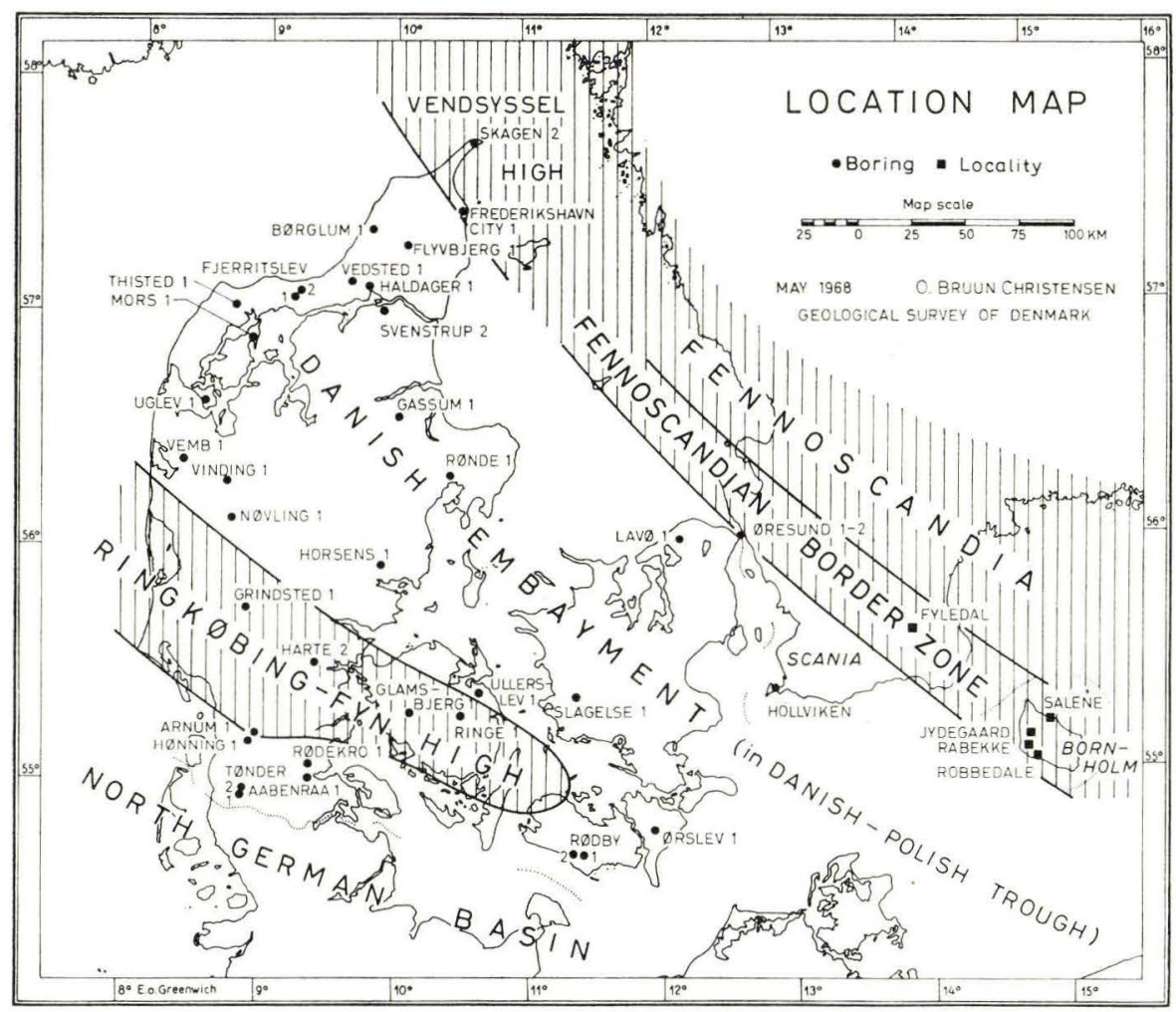

Fig. 1. Map, showing the situation of Slagelse no. 1, some other localities, and the Danish Embayment between the Ringkøbing-Funen Horst and the Fennoscandian Border Zone. 
"2637-2917 m. Shale, dark grey, beds of siltstone, light grey. Dip 16 ?-24$30^{\circ}-40^{\circ}$. 2768-2774 m.: Dictyonema sp. 2810-2812 m.: Monograptus crispus Lapworth.

2917-2944 m. Shale, black, pyritic, with spindle-shaped baryte crystals, "Alum Shale". Dip 10-12 ${ }^{\circ}$.

This series of strata is represented by seven cores amounting to a total length of about $20 \mathrm{~m}$. and by wash material from the intervals between them. The rocks are briefly characterized in the following.

\section{The black shale}

Level: 2917-2944 m. below the ground (core no. 13: 2929.03-2930.53 m.).

The core consists exclusively of black shale ("Alum shale"); it is impregnated with pyrite to a very high degree and much heavier than normal Cambrian alum shale; for this reason the cleavage is rarely parallel to the bedding planes; furthermore the rock shows the effects of numerous small dislocations so as to reduce the chance of finding determinable fragments of macrofossils to a minimum. In fact the only known macrofossil from the black shale is a small fragment of an inarticulate brachiopod (Obolus or Lingulella) found at the $2929.50 \mathrm{~m}$. level. ${ }^{1}$ The result of a search for microfossils by means of several chemical and physical methods was also negative.

In addition to the impregnating pyrite a 5-15 $\mathrm{mm}$. thick layer (or flat concretion?) of pyrite occurs at the $2929.10 \mathrm{~m}$. level. Numerous spindleshaped baryte crystals occur between $2929.60 \mathrm{~m}$. and $2929.13 \mathrm{~m}$. Such baryte crystals are krown from alum shale in several Scandinavian localities, where they occur scattered on the bedding planes. At Slagelse, however, they are accumulated so as to form veritable layers of baryte; these layers vary from $10 \mathrm{~mm}$. to $15 \mathrm{~mm}$. in thickness. As far as known the spindle-shaped baryte crystals crop up in the Upper Cambrian zone with Orusia lenticularis and Parabolina spinulosa and continue through the rest of the Olenid Series to vanish some distance above the base of the Lower Ordovician Dictyonema Shale. The stratigraphic position of the alum shale at Slagelse is problematic owing to the lack of palaeontological evidence. Part of the shale is probably of Upper Cambrian age, but it is possible that the lowermost part corresponds to part of the Middle Cambrian Paradoxides Series and that the uppermost part should be regarded as Lower Ordovician Dictyonema Shale.

1. The specimen is considered too fragmentary and poorly preserved to justify a description. 


\section{The grey shale and siltstone series}

Level: 2637-2917 m. below the ground (cores no. 7-12).

The cores represent only a very small part of the series, their total length amounting to about $17 \mathrm{~m}$. The levels of the cores are shown in fig. 2 (p. 10). The material at hand is a typical example of rhythmical sedimentation, the cores consisting of fine-grained, dark grey shale alternating with light grey siltstone. The shale beds range in thickness from about $0.5 \mathrm{~mm}$. to about $1 \mathrm{~m}$. and the thickness of the siltstone beds ranges from about $0.5 \mathrm{~mm}$. to about $0.5 \mathrm{~m}$.

Scattered grains of glauconite in siltstone occur in core no. 9 at the $2772.10 \mathrm{~m}$. level and furthermore between the 2772.65 and the $2772.85 \mathrm{~m}$. levels. A few small pebbles of dark shale, measuring up to $15 \mathrm{~mm}$. in diameter, occur in siltstone in core no. 7 between the 2637.70 and the $2638.00 \mathrm{~m}$. levels and furthermore in core no. 9 at the $2769.40 \mathrm{~m}$. level. Several siltstone layers in core no. 9 contain reworked phosphorite in the form of small black pebbles, measuring up to $15 \mathrm{~mm}$. in diameter; one of these is a poorly preserved fragment of a brachiopod; unfortunately, the specimen is indeterminable, but it shows some characters which are most frequently met with in certain Ordovician orthids; these phosphorite pebbles may have been transported by seaweed from a coast with exposed Ordovician sediments. Framboidal pyrite occurs in abundance in the cores no. 9-10.

The cores show evidence of tectonic stress. They are interwoven by small faults and slickensides, and the cleavage is rarely parallel to the stratification. Accordingly, the fossils are very poorly preserved, and the greater part of them must be regarded as indeterminable. It has been possible, however, to find a small number of determinable Silurian fossils in the cores no. 7-10, whereas the cores no. 11 and 12 are devoid of determinable specimens.

\section{The stratigraphic position of the Silurian at Slagelse}

The fauna of the shale-siltstone series consists of graptolites and a few representatives of other animal groups.

The cores contain the following fossils:

Core no. 7: Monograptus priodon (Bronn) ${ }^{1}$

Asteroids

Vertebrate scales

1. As to the recent tendency to name the species groups within the genus Monograptus the present writer has accepted Bulman's reasons against the use of most of these names (Bulman 1955, p. 69 and p. 92). 
Core no. 8: Dictyonema danicum n. sp,

Koremagraptus onniensis Bulman?

Monograptus priodon (Bronn)

Retiolites geinitzianus geinitzianus (Barrande)

Vertebrate scales

Core no. 9: Dictyonema perangustum n. sp.

Monograptus crispus Lapworth

Monograptus discus Törnquist

Monograptus exiguus exiguus (Nicholson)

Monograptus nudus nudus (Lapworth)

Monograptus priodon (Bronn)

Monograptus selandicus n. $\mathrm{sp}$.

Climacograptus sp.

Indeterminable spiriferid

Eurypterus? sp.

Vertebrate scales

Core no. 10: Dictyonema perangustum n. sp.

Monograptus crispus Lapworth

Monograptus exiguus exiguus (Nicholson)

Climacograptus spp.

Core no. 11: No determinable fossils

Core no. 12: No determinable fossils

The relation of the graptolite species to the cores no. 7-10 is shown in table I.

Table I.

\begin{tabular}{llllllll}
\hline Graptolite species & Cores & 7 & 8 & 9 & 10 & 11 & 12
\end{tabular}

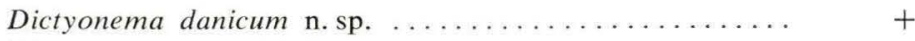

Dictyonema perangustum n. sp. ................ +

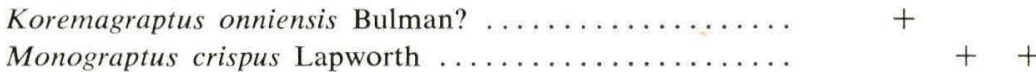

Monograptus discus Törnquist $\ldots \ldots \ldots \ldots \ldots \ldots \ldots \ldots \ldots \ldots+\ldots \ldots \ldots+\ldots \ldots \ldots$

Monograptus exiguus exiguus (Nicholson) $\ldots . \ldots \ldots \ldots \ldots \ldots+\ldots \ldots+$

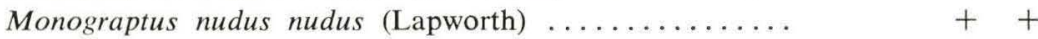

Monograptus priodon (Bronn) ................... + +

Monograptus selandicus $\mathrm{n}$. sp. ............... +

Retiolites geinitzianus geinitzianus (Barrande) $\ldots \ldots \ldots \ldots+\quad+$ 

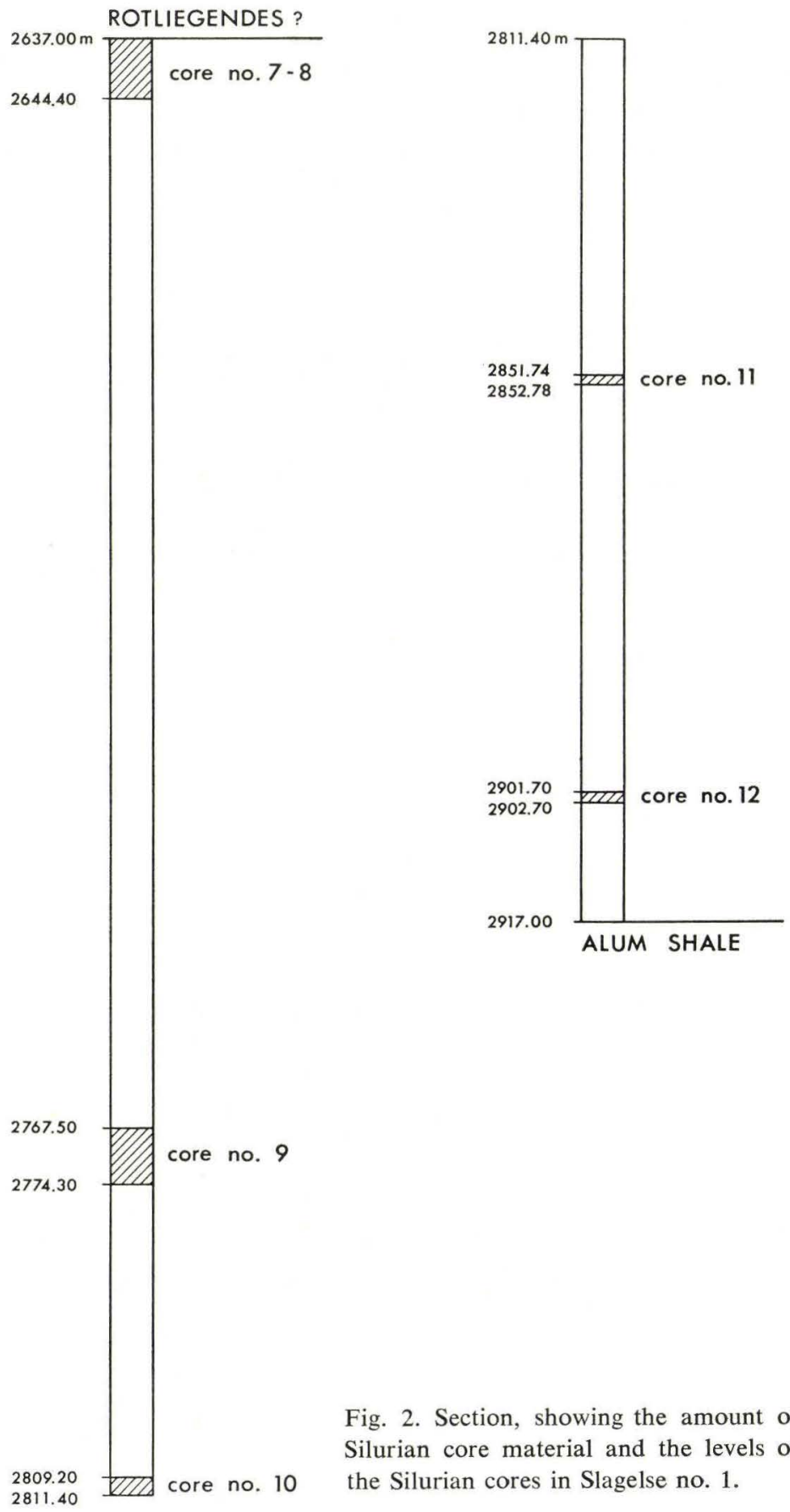

Fig. 2. Section, showing the amount of Silurian core material and the levels of the Silurian cores in Slagelse no. 1. 
The occurrence of Monograptus crispus in the cores no. 9 and 10 is very important; as far as known this species is restricted to zone no. 23, the Monograptus crispus zone, and accordingly the two mentioned cores belong to this stratigraphical level.

It appears from table II (below) that Monograptus discus, Monograptus exiguus exiguus, Monograptus nudus nudus, Monograptus priodon, and Retiolites geinitzianus geinitzianus are known as associates of Monograptus crispus. It deserves notice that, according to Elles \& Wood (1901-1918), Monograptus discus and Retiolites geinitzianus geinitzianus have their first appearance in the Monograptus crispus zone. In Slagelse no. 1 Retiolites geinitzianus geinitzianus occurs in core no. 8, and, accordingly, this core may be referred to the Monograptus crispus zone.

Monograptus priodon is the only determinable species in core no. 7; this species has a very long stratigraphic range, and, accordingly, a safe stratigraphic placement of this core must be left out of consideration. The core, however, is in direct contact with core no. 8, and, considering the fact that the total length of these cores is only $7.40 \mathrm{~m}$., it is possible that both cores belong to one and the same graptolite zone.

Table II.

British graptolite zones

(Elles \& Wood)

Graptolite species

from Slagelse

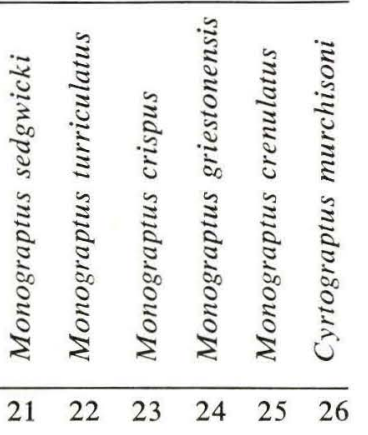

Dictyonema danicum n. sp.

Dictyonema perangustum n. $\mathrm{sp}$

Koremagraptus onniensis Bulman?

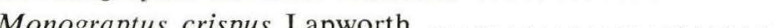

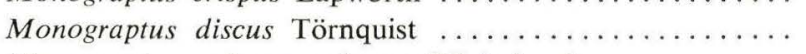

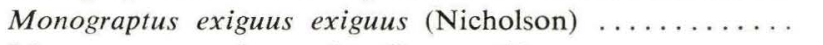

Monograptus nudus nudus (Lapworth) $\ldots \ldots \ldots \ldots \ldots \ldots \ldots+++{ }_{+}+{ }_{+}+$

Monograptus priodon (Bronn) ................... $++{ }_{+}+{ }_{+}$

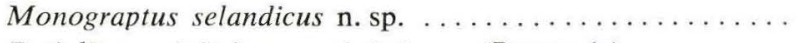

Retiolites geinitzianus geinitzianus (Barrande) $\ldots \ldots \ldots \ldots .++$ 
The cores no. 11-12 are found $40.34 \mathrm{~m}$. and $90.30 \mathrm{~m}$. below the fossiliferous Monograptus crispus beds (fig. 2, p. 10); the lack of fossils in these cores prevents a safe determination of their stratigraphic position; their lithological characters, however, agree fairly well with those of the cores $7-10$ so as to suggest a Lower Silurian age.

\section{Description of the fossils}

\section{Brachiopoda}

Class Articulata Huxley, 1869

Order Spiriferida Waagen, 1883

Family uncertain

Genus et sp. ind.

P1. 3, fig. 7.

Material: One small, fragmentary dorsal valve in siltstone.

Description: Dorsal valve very transverse, twice as wide as high, moderately convex, with acute lateral extremities, rectilinear hinge line, and broad, well marked fold. Surface ornament consisting of numerous capillae of approximately equal strength, spaced about 8 to the millimeter. The fold increasing very rapidly in width, divided by a well marked median depression with 3 capillae. Interior of valve unknown.

Dimensions:

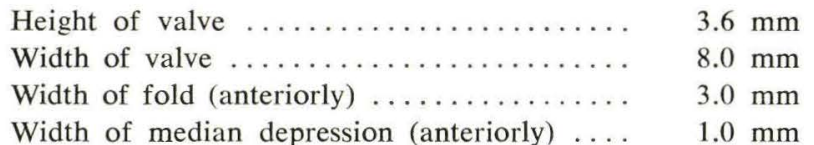

Remarks: The median capillae-bearing depression in the fold is a very remarkable feature; otherwise the general habit of the specimen is almost similar to that of certain transverse types of Cyrtospiriferidae Termier \& Termier and Spiriferidae King, but, owing to the lack of satisfactory diagnostic characters, a discussion of its systematic position must be left out of consideration.

Level: Core no. 9 (2767.5-2774.3 m.).

\section{Arthropoda}

Subphylum Chelicerata Heimons, 1901

Class Merostomata Dana 1852

Subclass Eurypterida Burmeister, 1843

Superfamily Eurypteracea Burmeister, 1845

Family Eurypteridae Burmeister, 1845

Genus Eurypterus De Kay, 1825 
Eurypterus? sp.

Pl. 1, fig. 4.

Material: One small segment of mesosoma in siltstone.

Description: Segment about five times as wide as long, moderately arched, with elevated anterior and posterior margins, and apparently without surface markings.

Dimensions: Width $4.0 \mathrm{~mm}$; length $0.9 \mathrm{~mm}$.

Remarks: The reference of the specimen to the genus Eurypterus is suggested by the occurrence of the raised anterior and posterior segmental margins which appear to be especially prominent and very frequently met with in that genus.

Level: Core no. 9 (2767.5-2774.3 m.).

\section{Echinodermata}

Subphylum Asterozoa Zittel, 1895

Class Stelleroidea Larmarck, 1816

Subclass Asteroidea De Blainville, 1830

Order and family uncertain

Genus et sp. ind.

Pl. 1, fig. 5.

Material: Several calcite bodies, occurring in pairs, appear as sections in siltstone and show the typical splitting of calcite crystals.

Description: The bodies have the outline of marginals; they are very small, the figured specimens, which are the biggest ones, measuring about 2-3 mm. in height.

Remarks: The fragments fail to show sufficient diagnostic characters, and, accordingly, any attempt at further determination must be abandoned.

Level: Core no. 7 (2636.7-2628.0 m.).

\section{Stomochorda}

Class Graptolithina Bronn, 1846

Order Dendroidea Nicholson, 1872

Family Dendrograptidae Roemer in Frech, 1897

Genus Dictyonema Hall, 1851

Dictyonema danicum $\mathrm{n}$. sp.

Pl. 1, fig. 2; pl. 2.

Material: A fragmentary rhabdosome in siltstone.

Diagnosis: Rhabdosome cyathiform (conical?); stipes slender, 0.1-0.2 $\mathrm{mm}$. in breadth, 17 per $\mathrm{cm}$; dissepiments thin, $0.03-0.05 \mathrm{~mm}$. in breadth, 12 per $\mathrm{cm}$.; meshes $0.2-0.8 \mathrm{~mm}$. in breadth. 
Description: Rhabdosome moderately spreading, cyathiform (conical?), with one more or less distinct zone of bifurcation per $\mathrm{cm}$. of axial length; proximal end unknown.

Stipes very slender, slightly undulating, and numbering 17 per cm.; dissepiments extremely fine; where these occur most frequently there are 14 per $\mathrm{cm}$., but the normal number appears to be 12 . The shape of the thecae and their number per $\mathrm{cm}$. is unknown.

Remarks: Dictyonema danicum resembles Dictyonema elegans Bulman, 1928 and Dictyonema delicatulum Lapworth, 1881, emend. Bulman, 1928, but it has only 17 stipes per cm whereas Dictyonema elegans has 20-24 and Dyctyonema delicatulum 22-23. Two North American species, Dictyonema tenellum Spencer, 1878 and Dictyonema densum Ruedemann, 1947, show some resemblance to Dictyonema danicum, but they differ in having a much greater number of dissepiments.

Level: Core no. 8 (2638.0-2644.4 m.).

\section{Dictyonema perangustum n.sp.}

Pl. 3; pl. 15, figs. 2-3.

1964. Dictyonema sp. Banke Rasmussen in Sorgenfrei \& Buch: Danmarks Geologiske Undersøgelse, 3. Række, no. 36, p. 75, pl. 11, fig. 112.

Material: A fragmentary rhabdosome in siltstone.

Diagnosis: Rhabdosome narrow, conical, rooted; stipes slender, $0.3 \mathrm{~mm}$. in breadth, 12 per $\mathrm{cm}$; dissepiments thin, 0.03-0.05 $\mathrm{mm}$. in breadth, 5-6 per cm.; meshes $0.3-0.6$ in width.

Description: Rhabdosome extremely narrow, acutely conical, with slightly concave sides, tapering gradually to a narrow rooted base; more or less distinct zones of bifurcation occur to the number of 4 in an axial length of $3 \mathrm{~cm}$.

Stipes slender; the autothecae are so poorly preserved that it is impossible to get an idea of their shape, but two of the stipes show rows of small swellings, indicating that they are present to the number of about 20 per $\mathrm{cm}$; shape of stolothecae and bithecae unknown; dissepiments extremely fine, generally straight, at right angles to the stipes, and spaced a relatively small number to the $\mathrm{cm}$.

Remarks: Dictyonema perangustum is remarkable for its narrow, moderately spreading rhabdosome. A rhabdosome of almost the same shape is found in Dictyonema stenactinotum Gurley in Bassler, 1909 from the Niagaran dolomite at Hamilton, Ontario, which differs from Dictyonema perangustum in having a more robust rhabdosome with much wider stipes.

Level: Core no. 9 (2638.0-2644.4 m.). 
Family Acanthograptidae Bulman, 1938

Genus Koremagraptus Bulman, 1927

Koremagraptus onniensis Bulman, 1927?

Pl. 1, fig. 3 (to the right); pl. 3, fig. 1.

1927. Koremagraptus onniensis Bulman: Annals and Magazine of Natural History, ser.

9, vol. 19 , pp. $345-346$, text-fig.; pl. 4 , figs. $1-5$.

Material: A poorly preserved, fragmentary rhabdosome in siltstone, measuring $6 \mathrm{~mm}$. in length and $5 \mathrm{~mm}$. in width.

Remarks: The specimen agrees very well with Bulman's description and figures; the poor state of preservation is the only reason why it has been determined with the addition of a mark of interrogation.

Level: Core no. 8 (2638.0-2644.4 m.).

Order Graptoloidea Lapworth, 1875

Family Retiolitidae Lapworth, 1873

Genus Retiolites Barrande, 1850

Retiolites geinizianus geinitzianus (Barrande), 1850

Pl. 3, fig. 2.

For bibliographic references see:

Elles \& Wood: "Monograph of British graptolites", Palaeontographical Society, London 1901-1918, pp. 336-338, and Ruedemann: "Graptolites of North America", Geological Society of America, Memoir 19, pp. 466-467, Baltimore 1947.

Material: A fragmentary rhabdosome in siltstone.

Remarks: The preserved part of the specimen agrees perfectly with the descriptions and figures of this well-known species.

Level: Core no. 8 (2638.0-2644.4 m.).

Family Monograptidae Lapworth, 1873

Subfamily Monograptinae Lapworth, 1873

Genus Monograptus Geinitz, $1852^{1}$

Monograptus crispus Lapworth, 1876.

Text-fig. 3.

1876. Monograptus crispus Lapworth, Geol. Mag., new ser., dec. 2, vol. 3, p. 503, pl. 20, fig. 7. - London.

1877. Monograptus crispus Lapworth, Proc. Belfast Natur. Field Club Appendix, p. 128, pl. 5, fig. 13.

1897. Monograptus crispus Perner, Palaeontogr. Bohemica, p. 34, text-fig. 30.

1. As to the recent tendency to name the species groups within the genus Monograptus the present writer has accepted Bulman's reasons against the use of these names (Bulman 1955, p. 69). 


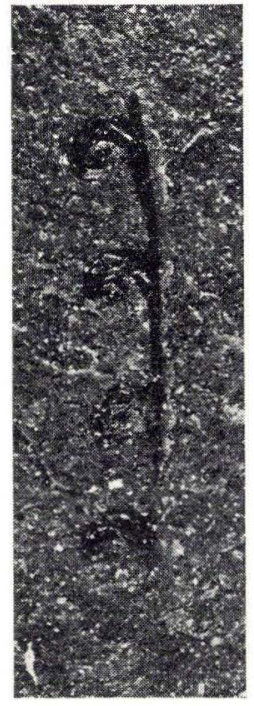

Fig. 3. Monograptus crispus Lapworth, about $\times 10$, core no. 10 . The figure is identical with Sorgenfrei \& Buch 1964, pl. 11, fig. 113. Phot. Chr. Westergaard.

1907. Monograptus gemmatus Törnquist, Lunds Univ. Årsskr., N. S., Afd. 2, Bd. 3, no. 5 , p. 21 , pl. 3 , figs. 24-31.

1912. Monograptus crispus Elles \& Wood, "Monograph of British graptolites", Palaeontogr. Soc. London, pt. 9, pp. 456-457, pl. 45, fig. 6.

1945. Monograptus crispus Waterlot, Protect. de la Republ. Francaise au Maroc etc., Notes et Mémoires n. 63, Laval, p. 83, pl. 38, fig. 393.

1951. Monograptus (Globosograptus) crispus Bouček \& Přibyl, Bull. intern. de l'Academie tchèque des Sciences, p. 8 , pl. 1, figs. $1-7$; p1. 2, figs. $1-3$.

1962. Globosograptus crispus Romariz, Revta. Fac. Cienc. Univ. Lisb. (C), 10, p. 262, pl. 19, fig. 2; pl. 22, figs. 10-15.

1964. Monograptus crispus Banke Rasmussen in Sorgenfrei \& Buch, Danmarks Geologiske Undersøgelse, ser. 3, no. 36, p. 130, pl. 11, fig. 113.

Material: A couple of fragmentary rhabdosomes in silty shale.

Remarks: The specimens from Slagelse agree very well with Elles \& Wood's exhaustive description and figures and also with Bouček \& Přibyl's description and figures of German specimens.

Level: Core no. 9-10 (2767.5-2811.4 m.).

Monograptus discus Törnquist, 1883

Pl. 4, fig. 3 .

1871. Nautilus veles Richter, Zeitschrift d. Deutsch. geol. Gesellschaft,p.234.

1876. Monograptus turriculatus Lapworth, pars, Geol. Mag., dec. 2, vol. 3, pl. 13, fig. $6 \mathrm{~b}$.

1877. Monograptus turriculatus Lapworth, Proc. Belfast Field Club, Appendix, p. 128, pl. 5, fig. 
1883. Monograptus discus Törnquist, Sveriges Geologiska Undersökning, ser. C, no. 57, p. $24-25$.

1892. Monograptus discus Törnquist, Acta Univ. Lundensis, vol. 28, p. 39, pl. 3, figs. 27-28.

1900. Monograptus veles Eisel, 39-42 Jahresber. d. Gesellschaft v. Freunden d. Naturwissenschaften in Gera, Reuss, p. 616.

1912. Monograptus discus Törnquist, Geol. Fören. i Stockholm Förhandl., vol. 34, pt. 6, pp. 617-619.

1912. Monograptus discus Elles \& Wood, Palaeontograph. Soc. London, p. 439, pl. 44, figs. 5a-d; text-figs. 302a-c.

1940. Monograptus discus Laursen, Danmarks Geologiske Undersøgelse, 2. ser., no. 64, p. 26 , text-fig. 18 ; pl. 1 , fig. 9 .

1970. Monograptus discus Rickards, Palaeontogr. Soc. London, p. 76, pl. 6, fig. 8.

Material: A few fragmentary specimens in siltstone.

Remarks: In spite of the poor state of preservation it appears clearly from pl. 4, fig. 3 that the material agrees fairly well with Törnquist's and Elles $\&$ Wood's descriptions and figures of this species which may hardly be confused with any other graptolite. As mentioned by Törnquist (1912, pp. 618619) it was originally introduced by Richter (1871) under the name of Nautilus veles. The present writer has accepted Törnquist's opinion that Richter's text has failed to give a definition, that his figure is not only insignificant, but even absolutely misleading, and, consequently, that the correct name must be Monograptus discus Törnquist.

Level: Core no. 8 (2638.0-2644.4 m.); core no. 9 (2767.5-2774.3 m.).

Monograptus exiguus exiguus (Nicholson), 1868

Pl. 4, fig. 4.

1868. Graptolites lobiferus var. exiguus Nicholson, Quart. Journ. Geol. Soc. London, vol. 24 , p. 533 , pl. 19 , figs. $27-28$.

1871. Graptolithus plumosus Baily, Mem. Geol. Surv. Ireland, Sheet 49, 50, p. 23, figs. $1 \mathrm{a}-\mathrm{c}$.

1876. Monograptus exiguus Lapworth, Geol. Mag., (2), vol. 3, p. 503, pl. 20, fig. 6.

1892. Monograptus exiguus Törnquist, Lunds Univ. Årsskr., vol. 26, no. 4, p. 25, pl. 2, fig. 22.

1899. Monograptus exiguus Törnquist, Lunds Univ. Årsskr., vol. 35, pt. 2, no. 1, p. 25 , pl. 4, figs. 26-28.

1912. Monograptus exiguus Elles \& Wood, Palaeontogr. Soc. London, p. 453, p1. 46, figs. 1a-d; text-figs. $312 \mathrm{a}-\mathrm{c}$.

1923. Monograptus exiguus Gortani, Palaeontogr. Ital., vol. 29, p. 13, pl. 1, figs. 23-27. 1939. Monograptus exiguus Münch, 25. Ber. d. Naturwiss. Ges. zu Chemnitz, p. 20, fig. $27 \mathrm{a}-\mathrm{d}$.

1942. Monograptus (Streptograptus) exiguus Bouček \& Přibyl, Mitteil d. Tschec. Akad. d. Wiss., Jahrg. 52, no. 1, p. 5, pl. 1, figs. 1-3; text-figs. 3a-d. 
1962. Monograptus exiguus exiguus Romariz, Revta. Fac. Ciênc. Lisb., (C), 10, p. 100, pl. 24 , fig 12 ; pl. 25 , fig. 1 .

1970. Monograptus exiguus Rickards, Palaeontogr. Soc. London, p. 78, pl. 8, figs. 3, 8.

Material: Six more or less fragmentary rhabdosomes in shale and siltstone. Description: The reader is referred to the very thorough description in Elles \& Wood's excellent monograph (1912, p. 453).

Remarks: The shape of the rhabdosome and the lobate nature of the thecae are sufficient to distinguish this species from the hitherto known Monograpti except Monograptus exiguus primulus Bouček \& Přibyl, 1942 (op. cit., p. 7, pl. 1, fig. 4; text-figs. 3e-g); Bouček \& Přibyl's subspecies, however, has a more robust rhabdosome with less prominent thecae. The specimens agree perfectly with Bouček \& Přibyl's figures of Monograptus exiguus exiguus from Bohemia and Thuringia where the graptolites of the Monograptus crispus zone appear to be preserved in the same way as those found at Slagelse.

Level: Core no. 9 (2767.5-2774.3 m); core no. 10 (2808.1-2809.2 m.).

Monograptus nudus nudus (Lapworth), 1880

Pl. 4, fig. 6.

1876. Monograptus Hisingeri Lapworth, Geol. Mag., dec. 2, vol. 3, p. 350, pl. 12, figs. 1a-c.

1880. Monograptus Hisingeri var. nudus Lapworth, Ann. Mag. Nat. Hist. (5), vol. 5, p. 156.

1883. Monograptus Hisingeri Tullberg, Sveriges Geol. Undersökning, ser. C, no. 55, p. 18 , pl. 2, figs. $45-48$.

1897. Monograptus Hisingeri Perner, Etudes sur les graptolites de Bohême, pt. 3 , sect. a, p. 11, pl. 13, figs. 2-4, 6 (non 5).

1899. Monograptus nudus Törnquist, Lunds Univ. Arsskrift, vol. 35, sect. 2, no. 1, p. 8 , pl. 1, figs. $18-20$.

1910. Monograptus nudus Elles \& Wood, Palaeontogr. Soc. London, p. 375, pl. 37, figs. 6a-e.

1940. Monograptus nudus Laursen, Danmarks Geologiske Undersøgelse, 2. ser., no. 64, p. 22, text-figs. $8 \mathrm{a}-\mathrm{b}$, pl. 1 , fig. 3 .

1940. Monograptus nudus nudus Přibyl, Mitteil. d. Tschech. Akad. d. Wiss., p. 2, pl. 1, figs. 6-9.

1952. Pristiograptus (Pristiograptus) nudus Münch, Geologica, Berlin, 7, p. 92, pl. 21, figs. 1a-b.

1962. Pristiograptus nudus nudus Romariz, Revta. Fac. Ciênc. Univ. Lisb., (C), 10, pl. 13, figs. 4-5?; pl. 16, fig. 1 .

1964. Monograptus sp. Banke Rasmussen in Sorgenfrei \& Buch, Danmarks Geologiske Undersøgelse, 3. ser., no. 36, pl. 11, fig. 111.

1970. Pristiograptus nudus Rickards, Palaeogr. Soc. London, p. 59, pl. 7, fig. 1.

Material: Two fragmentary rhabdosomes in shale, showing the proximal parí. 
Description: The reader is referred to the very thorough description in Elles \& Wood's excellent monograph (1910, p. 375).

Remarks: The specimen represented by pl. 4, fig. 6 agrees perfectly with the descriptions and figures of Lapworth, Törnquist, Elles \& Wood, and Přibyl. Banke Rasmussen's figure of “Monograptus sp.” (op. cit., 1964, pl. 11, fig. 111) is misleading; it shows hooked thecae in the proximal region of the rhabdosome, but, after a thorough examination of the specimen, it is now possible to state that the "hooks" are merely shadows, which have nothing to do with the rhabdosome itself, and that the specimen should be referred to Monograptus nudus nudus.

Level: Core no. 9 (2767.5-2774.3 m.); core no. 10 (2809.2-2811.4 m.).

\section{Monograptus priodon (Bronn), 1835}

1958. Monograptus priodon Urbanek, Palaeontologia polonica, no. 9, p. 43, pl. 1, figs. 1-2; text-figs. 17-20.

For further references see:

Elles \& Wood, Monograph of British Graptolites. - Palaeontogr. Soc. London, 1901-1918, p. 418.

Bassler, U.S. Nat. Mus., Bull. no. 92, p. 825. - Washington, D.C., 1915.

Přibyl, Bibliographic Index of Bohemian Silurian Graptolites, p. 32. Praha, 1948.

Material: Several small fragments in shale and siltstone.

Description: The reader is referred to the thorough descriptions in the above-mentioned papers by Elles \&Wood and Urbanek.

Remarks: The specimens are poorly preserved and not fit for illustration, but nevertheless the necessary observations and measurements could be accomplished so as to make determination of the fragments possible.

Level: Cores no. 7-8 (2637.0-2644.4 m.).

\section{Monograptus selandicus n. sp.}

Pl. 4, fig. 5.

Material: A fragmentary rhabdosome in shale.

Diagnosis: Rhabdosome small, moderately and regularly curved, widening from a slender thread-like initial portion to a maximum breadth of about $0.5 \mathrm{~mm}$. Thecae borne on the convex margin, 10 in $10 \mathrm{~mm}$., extroverted, free about $1 / 4$ of their length; overlap inconsiderable.

Description: Rhabdosome very slender and delicate, gradually widening from about $0.3 \mathrm{~mm}$. to about $0.5 \mathrm{~mm}$. (measured at the distal end of the oldest preserved theca and that of the youngest of these); the curvature of the 
rhabdosome corresponds approximately to a circle with a radius of about 4-5 mm.

The thecae are on the convex margin; they are of the same general type throughout, but the oldest of them are more slender and less prominent than the following ones. They are triangular, with a long, slender, adnate region the ventral walls of which show slightly concave curvature, and a shorter isolate region of which about one-half is involved in the formation of the hook-shaped extremity; the overlap is inconsiderable.

Remarks: The specimen shows much resemblance to Monograptus intermedius (Carruthers), but it differs from that species in having a more slender rhabdosome and more clearly subtriangular thecae.

Level: Core no. 9 (2767.50-2774.30 m.).

Family Diplograptidae Lapworth, 1873

Subfamily Climacograptinae Frech, 1897

Genus Climacograptus Hall, 1865

Climacograptus sp. indet.

Material: One specimen from core no. 9 (level: 2767.50-2774.30 m.) and four specimens from core no. 10 (level: 2809.20-2811.40 m.).

Remarks: The rhabdosomes are very poorly preserved and not fit for illustration; they must be regarded as absolutely indeterminable, and even the question of the number of species represented must be left unsettled.

In addition to the determinable graptolites the cores no. 7-10 contain numerous small indeterminable graptolite fragments; some of them may represent other species than the above-described ones which amount to about half the "normal graptolite community" of the Monograptus crispus zone.

\section{Vertebrata}

The cores no. 7-8 and 9 contain numerous fragmentary scales. The original substance of these has been replaced by jet so that nothing of the internal structure has been left. The writer has not been able to determine this poorly preserved material. Two scales, however, which show certain characteristic features are described in the following.

Scale no. 1

Pl. 4, fig. 8 .

Description: Outline apparently rhomboidal, with angles of about $60^{\circ}$ and 
$120^{\circ}$. Surface smooth except one of the corners (lower left in fig.) which shows an area marked by 12 nodules of equal size. The longer diagonal 2 $\mathrm{mm}$., the shorter one $1.3 \mathrm{~mm}$.

Level: Core no. 7 (2637-2638 m.).

Scale no. 2

Pl. 4, fig. 9 .

Description: Outline damaged, probably rhomboidal. Surface marked by two thick, prominent, rounded, parallel ridges, and a considerable number of minute, irregularly spaced granules. The preserved part of the scale is $0.35 \mathrm{~mm}$. in height and $0.45 \mathrm{~mm}$. in width.

Level: Core no. 9 (2767.50-2774.30 m.).

Trace fossils

Genus Rouaultia De Tromelin, 1877.

Rouaultia sp.

Pl. 1, fig. 1 .

Material: One specimen in siltstone.

Description: The preserved part of the specimen is $20 \mathrm{~mm}$. long and $3 \mathrm{~mm}$. wide, straight, slightly arched, smooth, with well-marked, narrow median furrow, and two indistinct lateral furrows.

Level: Core no. 9 (2767.50-2774.30 mm.).

\section{Framboidal pyrite}

Small pyrite bodies, which may be of biogenetic origin, occur in abundance in core no. 9 and core no. 10 as well as in the wash material from the intervals between the cores $8-9,9-10$, and 10-11. The pyrite occurs partly as single microscopic crystals, partly as small spherules, socalled framboids. The occurrence of framboidal pyrite in sediments has been recorded already in the last half of the 19th century, but the early papers dealing with these pyrite bodies are few and of minor importance, when compared with the modern studies. In 1958, however, L. G. Love published a paper, "Microorganisms and the presence of syngenetic pyrite", which revived the interest in framboidal pyrite and gave rise to an animated discussion and a considerable number of publications. Love's material orginated from the Lower Carboniferous (Pumpherton Shell Bed and the Pumpherton Oil Shales). When 
the framboidal pyrite had been disolved in nitric acid Love found insoluble residues which he interpreted as microfossils. During the following years Love added to the knowledge of framboidal pyrite in a long row of important publications (see the bibliographic list of Love \& Amstutz 1966, where also relevant papers of other authors are registered). The following pages are for use as a comparison of the Silurian framboids from Slagelse with some of those described from other geological systems and localities and for discussion of the possible relationship of framboids to microorganisms.

The stratigraphic range of framboidal pyrite is remarkable; they have been found in sediments from all systems from late Precambrian to the present times.

The framboids are spherules ranging in diameter from about 2 to about $100 \mu$. According to Love \& Amstutz (1966) the interior of the framboids shows numerous pyrite crystals, which are equal or subequal in size, and measurements show that there is a trend for the maximum crystal size to be related to the diameter of the framboid. The internal pyrite crystals are either unordered (i. e. apparently placed at random) or ordered (i. e. forming a pattern, apparently controlled by the laws of the crystal kingdom).

Very frequently the framboids are surrounded by a translucent sac which appears when the pyrite has been removed; this sac is regarded by Love as organic matter; other specimens are without sac; after treatment of framboids of the former type with brominated nitric acid the result is either a residual matrix body in sac or a sac without internal residue; the result of the same treatment of framboids without sac is either a matrix body or nothing at all (Love \& Amstutz 1966). The insoluble residual matrix bodies were regarded as microfossils by Love (1958) who described them as two new genera and species viz. Pyritosphaera barbaria and Pyritella polygonalis, and advanced the opinion that during their lifetime they produced the amount of hydrogen sulphide necessary for their own pyritization.

In 1962 Vallentyne published a paper, "Concerning Love, Microfossils, and Pyrite Spherules", in which Love's interpretation was seriously questioned. Vallentyne studied the "microfossils" derived from recent sediments and sedimentary rocks with regard to their behavior, when heated for two minutes over a Bunsen burner with the flame in direct contact with the specimens; this experiment resulted in the following statement: "The heating does produce some shrinkage and deformation, but the major part of the material is clearly not volatile". . . "Two other results of this experiment (repeated several times) are worthy of note: (a) external sacs lacking internal microforms similarly leave residue after ignition; and (b) the overall color of the microforms is not radically changed by the heat treatment..."; and, finally: "no charring was observed during incineration". According to 
Vallentyne (1962) "these data indicate that the microforms and external sacs are at least largely, though perhaps not totally, composed of inorganic materials".

Vallentyne (1962) also calls attention to the fact that the sulfur isotope for spherulitic pyrite does not provide critical data regarding the participation of organisms in spherule formation.

Staining of residual bodies and external sacs with acid Shiff reagent and Congo red was attempted by Love (1962) with positive results, and, accordingly, his assumption with regard to the biological origin of framboids was confirmed. Vallentyne (1962), however, calls attention to the fact that "some mineral particles also take up biological stains (personal communication from George Claus)". Staining with several other reagents was attempted by Vallentyne, but only safranin gave a positive result.

Analyses were made by Love (1963) in order to verify that the insoluble residues after removal of the pyrite with nitric acid are of organic composition. The material in question was derived from Namurian shale of the Derbyshire region. The carbon content was found to be 56 percent. This result was mentioned by Vallentyne (1962) who admitted that the carbon percentage "supports the notion that microforms, at least those derived from Paleozoic rocks, are composed of organic Matter". Later on Love \& Amstutz (1966) analysed material from the following geological occurrences: Rammelsberg Banderz (Devonian), Chattanooga shale (Devonian), shale (Upper Carboniferous), and Mt. Isa shale (Precambrian). The result of these analyses was that the carbon percentage of the Palaeozoic framboids vary from 35.53 to 57.54, whereas that of the Precambrian ones amounts to 71.41 .

Compared with the relatively high carbon percentage of the mentioned Palaeozoic framboids, that of specimens from recent sediments is remarkably low. In recent framboids from Queechy Pond, N. Y., the carbon content was found to be 0.67 percent and a second sample from the same locality contained only negligible carbon (Love 1962a). It may be of interest in this connection that analyses of five samples of framboids from the Silurian at Slagelse by means of electron micro probe revealed a $0.6-0.8$ percent carbon content, which is about the same as that of the mentioned, recent framboids from Queechy Pond.

Finally Vallentyne (1962) calls attention to the following difficulties in Love's interpretation:

1. "Microorganisms with structures similar to those of the microforms have never been observed outside pyrite spherules, even in recent sediments, where the spherules reach concentrations of $10^{6}$ per $\mathrm{ml}$. Surely one 
could expect to find some intermediates between the supposed microorganism and a pyrite spherule if such processes occurred".

2. "It has not yet been possible to assign the microforms to any definite taxonomic group. This seems rather surprising if the microforms are truly microfossils in view of their extensive distribution in both space and time",

3. "Several characteristics of the microforms raise doubts about their supposed biological origin: (a) the size range is large (two to 100 microns for the spherules, two to 35 microns for Pyritosphaera barbaria); (b) the same forms occur in waters of quite diverse salinity; and (c) they have persisted with an apparently unchanged form ever since the early part of the Cambrian period. None of these considerations is, however, really critical".

4. "The deposition of solid pyrite in a cell as implied by Love (1958) must surely be a microbial equivalent of suicide. It is difficult to conceive of any selective advantage to such a process".

After eight years of animated discussion Love \& Amstutz (1966) suggest "that there is no evidence that pyrite framboids represent any form of fossil microorganism or have a direct (as distinct from indirect) biogenetic origin. In rocks, as in sediments, they may be found within organic matter which must have been lying in the sediment at the time of formation". Love \& Amstutz, however, maintain that "the presence of an organic matrix within the framboid is still unexplained when it occurs in rocks".

The preceding brief summary of research and discussion may be sufficient to show that much has been said pro et contra a biogenetic origin of framboids. As far as the Silurian material from Slagelse is concerned the present writer's study does not contribute much to the solution of the problem, but some new observations may be worthy of note.

The Silurian framboids from Slagelse have been treated with 5-normal nitric acid without leaving any insoluble organic residues comparable with the sacs and matrix bodies, described and figured by Love $(1958,1962)$ and Love \& Murray (1963).

The numerous polished sections of framboids from Slagelse show that these specimens belong exclusively to the unordered type of Love \& Amstutz (1966); the very remarkable fact that framboids of the ordered type have not been observed confirms Love's suggestion (1962a) that pyrite spherules might have more than one kind of origin.

According to Love \& Amstutz (1966) "groupings of two to seven framboids generally occur randomly distributed but are occasionally more abundant in certain microscopic horizons". The Silurian material from Slagelse, 
however, clearly shows that grouping is so common that it must be regarded as normal and typical and that in a group the size of the framboids is equal (pl. 5-6). Such groups are referred to in the following as superframboids.

The diameters of the superframboids from the Silurian of Slagelse vary from $180 \mu$ to $550 \mu$. It appears clearly from the diagram (fig. 4, p. 26) that the diameters of the framboids are not in essential degree dependent on those of the superframboids. The framboids range in diameter from $11 \mu$ to $42 \mu$; one third of them have a diameter of $11 \mu$, and about one third have a diameter of $33 \mu$. The result of these measurements is suggestive of the existence of more than one "type" of superframboids and indicates that the unordered type of framboid might be derived from different sources.

Removal of the pyrite from some of the superframboids by means of nitric acid revealed matrix bodies consisting of quartz with rounded natural casts of the framboids and their periferal crystals (pl. 9-11). It deserves notice that in one of these specimens( pl. 10, fig. 2 ; pl. 11) the natural casts of the framboids contain a central, spherical silicification which might cover or replace a possible organic matrix body.

The situation of the superframboids in the sediments is also worthy of note. As mentioned (p. 8) the Silurian at Slagelse is a typical case of rhythmical sedimentation, the sequence consisting of very fine-grained, dark shale, rich in organic matter, alternating with light grey, fine-grained siltstone. The superframboids occur at the bottom of the siltstones, in contact with the dark shales or nearly so. These facts may lead to the following interpretation: The Silurian at Slagelse was deposited in a basin more or less isolated from oceanic waters. The dark shales, which are devoid of burrowing and other bottom-living fauna, clearly indicate still, foul bottom waters or mud where aerobic life was hampered by a high concentration of hydrogen sulphide. From time to time the basin was refreshed by a moderate amount of oceanic waters, resulting in admission of small phosphorite pebbles, a little glauconite, a few representatives of the shelly fauna, and, last but not least, the spherical microorganisms which, owing to the influence of the hydrogen sulphide, gave rise to the formation of the pyritic framboids and superframboids.

The hydrogen suphide may have been the result of the biochemical activity of bacteria or other microorganisms. Pl. 12, fig. 1 shows a polished section of Silurian rock, containing a few isolated crystals of pyrite, numerous framboids, and numerous small, worm- or sausage-shaped bodies with spherical swellings at both ends, which may possibly be the microorganisms (Bacteria?) responsible for the production of hydrogen sulphide.

As to the nature of the insoluble central body found by Love (1958) in the framboids the present writer is inclined to suscribe to Love's opinion (1962) 


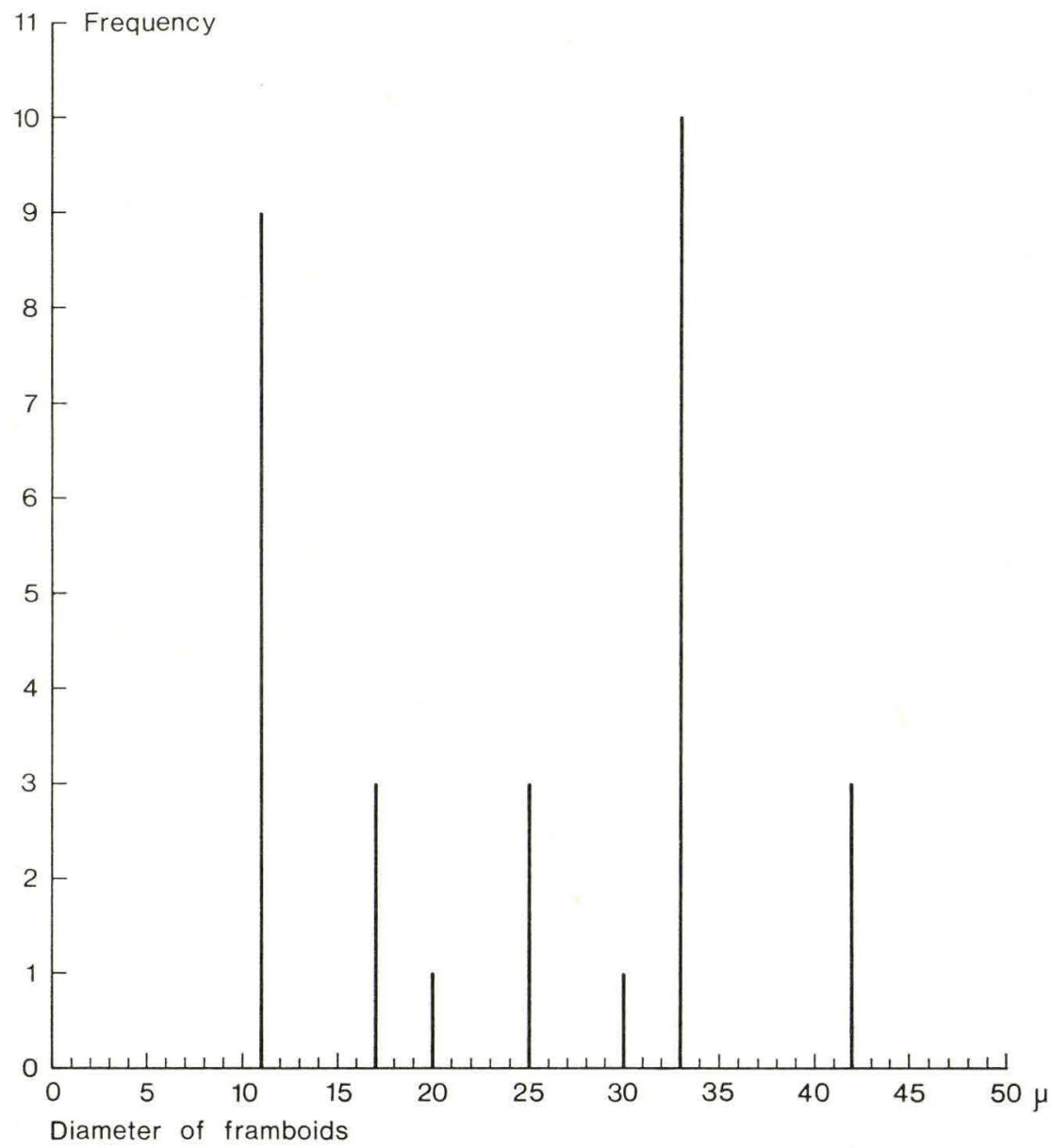

Fig. 4. Diagram showing frequency and size of framboids in 30 complete superframboids.

that it may be interpreted as the crystal-deformed remains of a microorganism. There is reason to believe that this microorganism was spherical and single (forming framboids) or compound (forming superframboids). It is of interest in this connection that certain primitive algae (Cyanophyta and others), fossil as well as recent, may be taken into consideration as possible relatives. Schopf \& Blacic (1971) for instance describe and figure Late Precambrian spherical algae, single as well as compound, having about the same size as framboids and superframboids. 
Summary of new observations and conclusions

1. The carbon content of the Silurian framboids from Slagelse amounts to $0.6-0.8$ percent; although this is much less than the carbon content of younger Palaeozoic framboids, it is nevertheless regarded as too much to be attributed to contamination.

2. The Silurian framboids from Slagelse have been treated with 5-normal nitric acid without leaving any insoluble organic residuals comparable to the sacs and matrix bodies described and figured by Love (1958, 1962) and Love \& Murray (1963).

3. The Silurian framboids from Slagelse belong exclusively to the unordered type of Love \& Amstutz (1966). The absence of ordered framboids confirms Love's suggestion (1962) that pyrite spherules might have more than one kind of origin.

4. Grouping of framboids does not occur haphazardly; they unite so as to form spherical bodies which are referred to as superframboids in the present paper.

5. All framboids of one and the same superframboid are of equal size.

6. The size of the framboids is not related to the size of the superframboids.

7. Measurements indicate that the unordered type of framboid might be derived from different sources (species?).

8. Pyritization of framboids and superframboids must have taken place shortly after deposition in the sediment.

9. One matrix body of a superframboid, consisting of quartz, shows natural casts of the framboids and, at the centres of these, silicified, spherical bodies which might cover or replace a possible organic matrix body.

10. In the rhythmical Silurian series of strata the framboids and superframboids occur at the bottom of the siltstones, practically in contact with the dark shales, indicating that the repeated ingression of pure sea water resulted in admission of spherical microorganisms which were changed into pyritic framboids and superframboids as soon as they were exposed to the hydrogen sulphide of the still, foul bottom water or mud.

11. The hydrogen sulphide is supposed to be the result of the biochemical activity of associated microorganisms (Bacteria?).

12. Among primitive algae (Cyanophyta and others), fossil as well as recent, are found several spherical genera and species which agree with the framboids and superframboids with regard to size and occurrence of single as well as compound specimens; accordingly, the framboids and superframboids might be of algal origin. 


\section{Permian rocks and fossils}

The sediments between the Zechstein evaporites and the Silurian rocks has been briefly characterized as follows (Sorgenfrei \& Buch 1964):

"2583-2626 m. Limestone, grey, and shale, dark grey, thinly laminated. Dip 6-7 .

2626-2637 m. Claystone, dark red, silty, non calcareous."

The dark red, silty, non calcareous claystone

Level: $2626-2637 \mathrm{~m}$. below the ground.

This part of the Permian is only represented by wash material. Accordingly, it is impossible to get an idea of the chronological succession of the rocks within this interval. The material contains the following three types of rock fragments: Red, silty clay, red to reddish brown, silty claystone, and light, reddish grey limestone. In addition to these rock fragments occur numerous small druses of selenite. The red colour of the rocks and the abundance of selenite druses are suggestive of arid conditions during the depositions of the sediments. The rock fragments do not show symptoms of tectonic stress; in this respect they form a striking contrast to the Silurian rocks which are interwoven by small faults and slickensides.

The stratigraphic position of the sediments is unknown owing to the lack of selenite druses are suggestive of arid condions during the depositions of succeeded directly by grey dolomite and shale with Upper Permian fossils. The material is unsatisfactory, but the writer is of opinion that the data at hand are suggestive of a Lower Permian (Rotliegendes) age.

\section{The grey dolomite ${ }^{1}$ and dark grey, thinly laminated shale}

Level: $2583-2626 \mathrm{~m}$. below the ground (cores no. 5-6).

This series of strata is developed as grey dolomite beds, alternating with

1. The rock was named limestone by Sorgenfrei \& Buch (1964), but dolomite is absolutely predominant. 
dark grey, thinly laminated, perfectly cleaving shale; the shale is easily split into plates as thin as paper. The rocks are extremely fine-grained; the dolomite beds are somewhat silty, and, accordingly, less fine-grained than the shale; in other words, these strata are a result of rhythmical sedimentation.

From top to bottom the strata contain plant remains in abundance, representing three different members of the class Hepaticopsida. This is indeed a very poor flora, but, cons.dering the extremely deficient knowledge of fossil hepatics, the discovery of this new, hitherto unknown biotope is very remarkable. These plants have probably lived in the immediate neighborhood of the finding place.

A search for microfossils resulted in the discovery of gymnosperm pollen; an extremely predominant type of these belongs to the genus Lueckisporites which is well-known from Zechstein sediments. A probable Zechstein age also appears from the position of the strata between the red, silty claystone and the evaporite series.

\section{Description of the fossils}

Bryophyta Schimper, 1879

Class Hepaticopsida Rothmaler, 1951

Order Calobryales D. H. Cambell, 1920

Family Haplomitriaceae Dědecěk, 1826

Genus Gessella n. g. ${ }^{1}$

(Type species: Gessella communis n. sp.)

Diagnosis: Haplomitriaceae having very long, ligulate to lanceolate or sublanceolate leaves with a small denticle on distal extremity and smooth or striated surface.

Gessella communis n. sp.

Pl. 12 fig. 2; pl. 13, figs. 1-2; pl. 14, figs. $1-3$ and 5; pl. 15, fig. 4 .

Material: Numerous leaves, a couple of more or less fragmentary sterile shoots, two capsules with spores, and a couple of fragmentary rhizomes. Diagnosis: Surface of leaves smooth.

Description: Rhizome relatively long, slender. Sterile shoot robust, relatively high, triradial. Leaves transversely inserted, somewhat remote, erect-

1. The generic name is derived from the locality name Slagelse by changing the order of succession of the relevant letters. 
spreading to spreading, unistratose, about 50-60 cells wide, very long, ligulate to lanceolate or sublanceolate, with a small median denticle on rounded distal extremity and smooth surface; no differentiation into lateral leaves and underleaves; cells oblong, subquadrangular to quadrangular, forming parallel longitudinal rows. Capsule unistratose, three times as long as wide, evenly rounded distally. Spores globular, with coarsely verrucose surface. Elaters not observed; they may have been too fragile.

\section{Dimensions:}

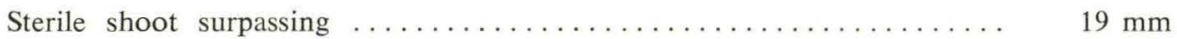

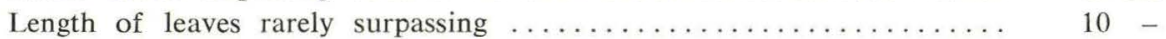

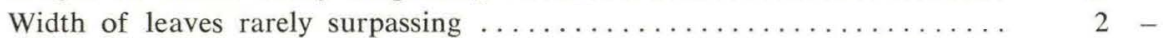

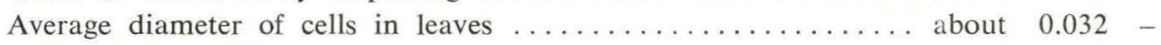

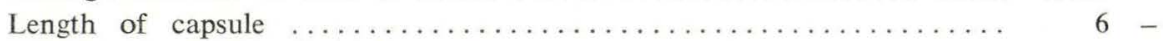

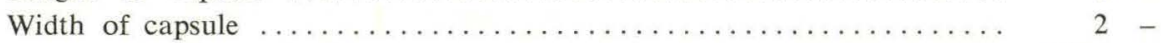

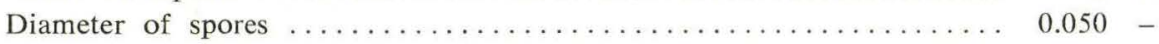

Remarks: The characters mentioned in the above description should justify the reference of Gessella communis to the Haplomitriaceae. The very long ligulate-lanceolate, perfectly symmetrical leaves are regarded as a primitive character. The fact that only two capsules with spores have been found in the abundant material is suggestive of predominant vegetative reproduction.

Level: Cores no. 5-6 (2583-2605 m.).

Gessella striata n. g. et n. sp.

Pl. 13, fig. 4; pl. 14, fig. 4.

Material: A sterile shoot and a single leaf.

Diagnosis: A Gessella having leaves with longitudinal striation and acutely pointed extremity.

Description: Sterile shoot, robust, relatively high, clearly triradial. Leaves transversely inserted, erect-spreading to spreading, unistratose, about 100 to 150 cells wide, long, ligulate to lanceolate, terminating distally into a small denticle; no clear differentiation into lateral leaves and underleaves; cells oblong, quadrangular to subquadrangular, forming parallel longitudinal rows; surface of leaves coarsely striated by parallel, irregularly spaced longitudinal furrows or wrinkles.

\section{Dimensions:}

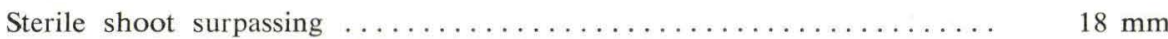

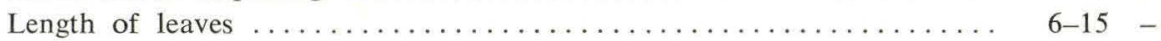

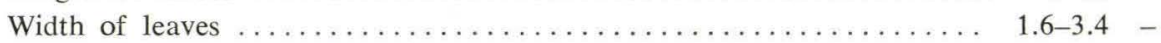

Average diameter of cells in middle part of leaves about $\ldots \ldots \ldots \ldots .0 .020 \quad$

Level: Cores no. 5-6 (2583-2605.1 m.). 
Order Jungermanniales Rup, 1817

Family uncertain

Genus Jungermannites Goeppert, 1845, emend. Steere, 1946

Jungermannites selandicus $\mathrm{n}$. $\mathrm{sp}$.

Pl. 12, fig. 2; pl. 15, fig. 1.

Material: A fragmentary shoot.

Diagnosis: Oblong, rounded, imbricate leaves with surface marked by shallow excavations.

Description: Shoot somewhat anisophyllous. Leaves rounded, convex, densely imbricate; surface with numerous shallow, rounded depressions; cells minute, rounded quadrangular.

The poor state of preservation has made it impossible to decide if the smaller leaves (pl. 15, fig. 1) are amphigastria or lobes belonging to the larger leaves.

\section{Dimensions:}

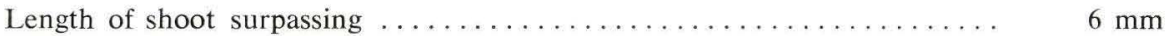

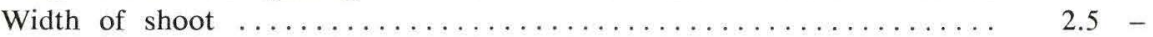
Average diameter of rounded depressions in leaf surface ........ 0.083 Average diameter of cells ........................ 0.017 _

Level: Core no. 5 (2583-2596.1 m).

\section{Microflora}

As mentioned above (p. 30), the grey dolomite and dark grey laminated shale (cores no. 5-6) contain dispersed pollen and spores. The composition of this material is remarkable; the slides prepared for microscopical study contain only four different types; one of these occurs in great abundance, whereas the others are represented by single specimens. The limited material does not contribute to the discussion of classificatory problems.

Anteturma Pollenites Potonié, 1931

Turma Saccites Erdtman, 1947

Subturma Monosaccites Chitaley emend. Potonié \& Kremp, 1954

Genus Cordaitina Samolovich, 1953.

Cordaitina? sp.

Text-fig. 5.

Material: One somewhat deformed specimen. 
Fig. 5. Cordaitina? sp., $\times 750$.

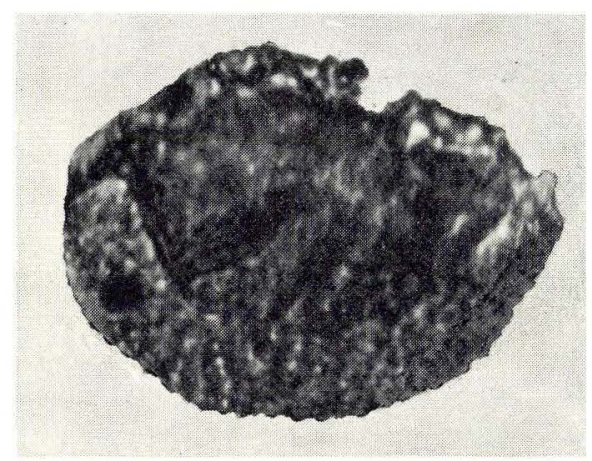

Description: Monosaccate, amb probably circular before deformation. Tetrad markings and defined germinal area absent. Corpus probably circular before deformation, diameter about two-thirds that of total diameter, exine of corpus with random plications and rather coarse ornamentation consisting of irregularly spaced grana. Saccus exine coarsely granulate, the irregularly spaced grana showing in places a tendency to form more or less radiating rows.

Dimensions: Total diameter about $80 \mu$; corpus diameter about $53 \mu$; diameters of grana about $0.1 \mu$.

Level: Core no. 6 (2596.1-2605.1 m.).

Remarks: The specimen agrees with the form genus Cordaitina as defined by Balme (1970); it may represent a new species, especially characterized by the coarsely granulate ornamentation described above, but the somewhat imperfect state of preservation does not allow of any safe use of it as a holotype.

Subturma Disaccites Cookson, 1947

Infraturma Striatiti Pant, 1954

Genus Lueckisporites Potonié \& Klaus emend. Klaus, 1963.

Lueckisporites parvulus n. $\mathrm{sp}$.

Pl. 14, fig. 6.

Material: Several fairly well preserved specimens and a great number of deformed ones; some specimens have been deformed to such a degree that they may easily be mistaken for other genera.

Diagnosis: Very small. Corpus transversely oval. Transverse polar cleft of cappa very short and narrow. Exoexine of cappa and sacci with distinctly marked, very irregularly meshed reticulum. 
Description: Disacate. Corpus transversely oval. Cappa divided by a very short, narrow, transverse polar cleft. Reticulum of cappa and sacci distinct, consisting of irregularly distributed meshes of much varying sizes and outlines. Sacci almost hemispherical in polar view, with a pronounced distal inclination. Cappula approximately rectangular, about one-fourth the breadth of corpus.

Dimensions of holotype: Total breadth $46 \mu$; corpus breadth $32 \mu$; corpus height $26 \mu$; breadth of cappula $8 \mu$; meshes of reticulum varying in diameter from $0.4 \mu$ to $5 \mu$.

Level: Cores no. 5-6 (2583-2605.1 m.).

Remarks: Lueckisporites parvulus is readily distinguished from the hitherto known species by its small size and the remarkable irregular pattern of the reticulum. In western Europe the genus Lueckisporites is a typical member of the late Permian microflora, and it is one of the most important gymnosperm pollen of the Zechstein. Lueckisporites virkkiae Potonié \& Klaus (the type species) characterizes the Zechstein sediments of western Europe; it is therefore a remarkable fact that this well-known Zechstein species has not been observed in the material from Slagelse.

\section{Unclassified material}

Text-figs. 6a-b.

The two figured specimens are unica. The present writer has not been able to refer them to genus and species; accordingly, they are introduced here merely as unnamed members of the microflora.

Level: Core no. 6 (2596.1-2605.1 m.).

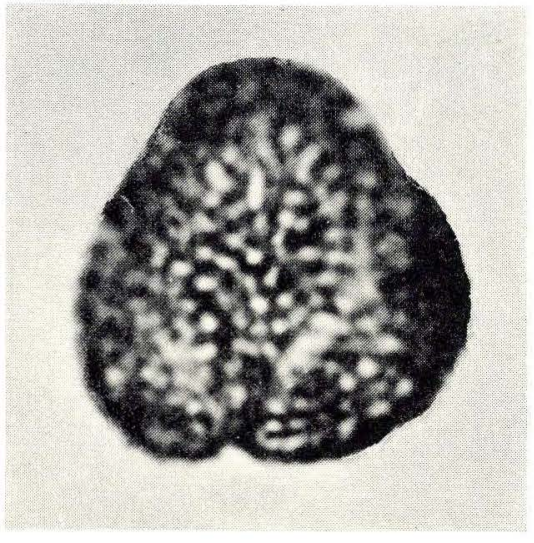

a

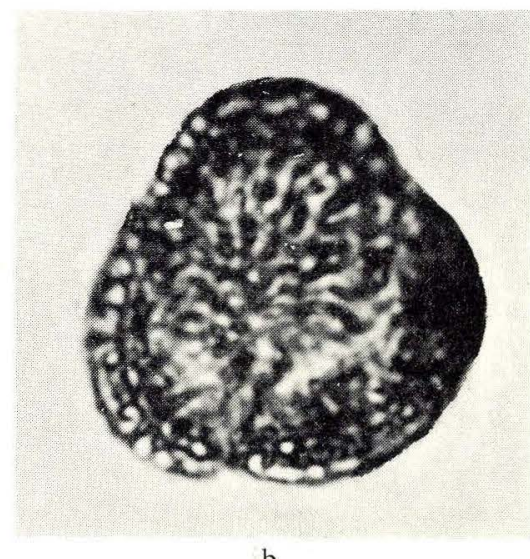

b

Fig. 6. Undetermined specimen, $\times 750$; a: proximal focus, $b$ : equatorial focus. 


\section{Outline of palaeogeography and geological history}

The importance of the Ringkøbing-Funen Ridge as part of an effective barrier during the deposition of the Lower Cambrian Holmia kjerulfi beds has been emphasized by the writer at an earlier occasion (C. Poulsen 1969). The southwestern side of the Danish Embayment is formed by the Ringk $\phi$ bing-Funen Ridge, whereas the northeastern side is formed by the Fennoscandian Border Zone (p. 6, fig. 1), and these boundaries appear to have been rather permanent during the Palaeozoic. Slagelse no. 1 is situated in the western part of the Danish Embayment not far from the northeastern flank of the Ringk $\varnothing$ bing-Funen Ridge. The ridge, which consists of Precambrian gneiss, may be interpreted as a horst; it may be worthy of note in this connection that it is practically parallel to the horst system of Scania. It appears from borings on top of the horst that Upper Permian sediments (Zechstein) are entirely lacking. On the other hand Zechstein sediments (evaporites) are known from several borings along the flanks of the horst. In these localities the Zechstein sediments have been hit at considerably varying levels as shown in the following list.

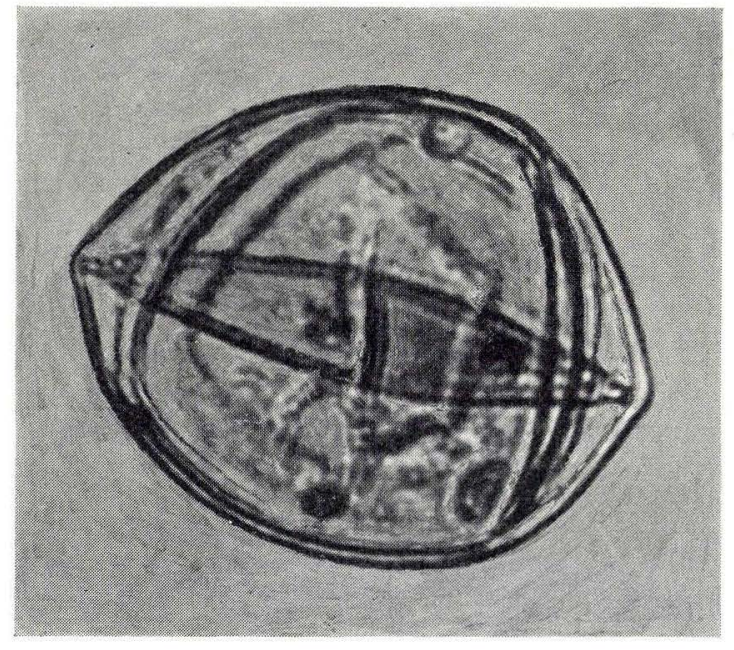

Fig. 7. Undetermined specimen, $\times 750$. 
Borings along the southwestern side of the horst:

Aabenraa: Top of Zechstein $1851 \mathrm{~m}$. below the ground

Arnum: $\quad$ - $\quad$ - 1747 - $\quad$ - $\quad$ -

Hønning: - $\quad$ - $\quad-\quad 1991$ - $\quad$ - $\quad-\quad$

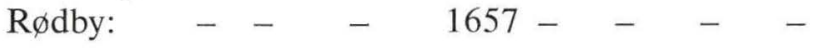

Borings at the northeastern side of the horst:

Nøvling: Top of Zechstein $3522 \mathrm{~m}$. below the ground.

Slagelse: Top of Zechstein $2254 \mathrm{~m}$. below the ground.

These differences should probably be interpreted as results of local movements in a tectonic block mosaic along the horst. The facts that the boring at Nøvling penetrated more than $200 \mathrm{~m}$. Ludlowian rocks, and that this series is missing at Slagelse, show that local movements took place already during the Silurian.

The development of the Palaeozoic at Slagelse is outlined below. The boring was stopped in the Lower Cambrian Slagelse Quartzite, and, accordingly, the nature of the basal Lower Cambrian is unknown. The Slagelse Quartzite is probably a stratigraphic equivalent of the Balka Quartzite on the island of Bornholm, i. e. corresponding to the Mobergella holsti zone of Sweden.

The progressive early Cambrian transgression in the Danish Embayment resulted in deposition of dark grey, silty shale with index fossils of the Holmia kjerulfi fauna. The siltstone is $22 \mathrm{~m}$. thick but the core at hand (core no. 14) covers only an interval of one m.; it is therefore possible that the siltstone also comprises the zone with Holmia torelli (Moberg) and the zone with Strenuella (Comluella) linnarssoni Kiær (C. Poulsen 1969).

It is a well-established fact that the Balto-Scandian basin was subjected to repeated changes of level after deposition of the Holmia beds, and, consequently, the Middle Cambrian of that region is incomplete in most localities. This seems also to be the case at Slagelse, where the Holmia Series is directly succeeded by alum shale; satisfactory evidence of the presence of Middle Cambrian is entirely lacking. In the Balto-Scandian basin the deposition of black mud, which gave rise to the formation of alum shale, commenced during the later part of the Paradoxides paradoxissimus stage and in Scania, and on Bornholm it is by far the predominant facies of the Middle and Upper Cambrian and of the basal Tremadoc. The stratigraphic range of the alum shale at Slagelse is unknown owing to the lack of determinable fossils, but, as a rule, the bulk of the alum shale belongs to the Upper Cambrian. 
Review of the palaeozoic of Slagelse no. 1 .

\begin{tabular}{lll}
\hline \multicolumn{1}{c}{ Lithology } & \multicolumn{1}{c}{ Biostratigraphy } & \multicolumn{1}{c}{ Systems } \\
\hline $\begin{array}{l}\text { Dolomite, anhydrite, } \\
\text { rock salt, etc. }\end{array}$ & Not referred to zone & $\begin{array}{l}\text { Upper Permian } \\
\text { (Zechstein) }\end{array}$ \\
\hline $\begin{array}{l}\text { Grey dolomite and dark } \\
\text { grey thinly laminated } \\
\text { shale }\end{array}$ & Not referred to zone & \\
\hline $\begin{array}{l}\text { Dark red, silty, } \\
\text { non-calcareous claystone }\end{array}$ & Not referred to zone & $\begin{array}{l}\text { Lower Permian } \\
\text { (Rotliegendes) }\end{array}$ \\
\hline & & Carboniferous \\
\hline
\end{tabular}

Devonian

\begin{tabular}{|c|c|c|}
\hline & & $\begin{array}{l}\text { Middle and Upper } \\
\text { Silurian }\end{array}$ \\
\hline \multirow[t]{2}{*}{$\begin{array}{l}\text { Grey shales } \\
\text { and siltstones }\end{array}$} & $\begin{array}{l}\text { Zone with Monograptus crispus } \\
\text { and possibly older zones }\end{array}$ & $\begin{array}{l}\text { Lower Silurian } \\
\text { (Llandovery) }\end{array}$ \\
\hline & & Ordovician \\
\hline \multirow{3}{*}{ Black shale (Alum shale) } & $\begin{array}{l}\text { Assemblage-zone of Olenidae or } \\
\text { possibly of early Anisograptidae }\end{array}$ & \multirow{3}{*}{$\begin{array}{l}\text { Upper Cambrian } \\
\text { (Upper part possibly } \\
\text { Lowermost Ordovician. } \\
\text { Lower part possibly } \\
\text { Uppermost Middle } \\
\text { Cambrian) }\end{array}$} \\
\hline & Assemblage-zone of Olenidae & \\
\hline & $\begin{array}{l}\text { Assemblage-zone of Olenidae } \\
\text { or possibly of Paradoxididae }\end{array}$ & \\
\hline \multirow{2}{*}{ Dark grey, silty shale } & $\begin{array}{c}? \\
\text { Zone with Holmia kjerulfi }\end{array}$ & \multirow{4}{*}{ Lower Cambrian } \\
\hline & ? & \\
\hline Quartzite & $\begin{array}{l}\text { Zone with Diplocraterion and } \\
\text { Scolithos }\end{array}$ & \\
\hline ? & ? & \\
\hline
\end{tabular}

The alum shale is directly succeeded by a series of grey shales alternating with siltstone. The upper half of these beds contains a graptolite fauna which indicates the presence of the Monograptus crispus zone (Upper Llandovery); no determinable fossils have been observed in the lower half of this series of strata, which, judging from the lithological character, must belong to the same cycle of sedimentation. In other words: The hiatus between the 
alum shale and the Silurian rocks is very considerable; it indicates a total regression between the late Cambrian (or, possibly, the Tremadoc) and the early Silurian. Considering the fact that the thickness of the Ordovician on the island of Rügen, about $130 \mathrm{~km}$. southeast of Slagelse, amounts to about 1500 m. (Jäger 1967; Franke 1967) the remarkable Ordovician hiatus at Slagelse serves to confirm the theory of local movements in a tectonic mosaic along the northeastern flank of the Ringkøbing-Funen Horst. It is interesting in this connection that Lower Permian sediments rest directly on top of the Ordovician on the island of Rügen; accordingly this island may be part of the same tectonic border zone as the Slagelse and Nøvling regions.

The dip of the alum shale is about $10-12^{\circ}$, whereas that of the Silurian rocks is more varying, 16?-24-30-40 (Sorgenfrei \& Buch 1964), and, as mentioned p. 8, these beds show much evidence of tectonic stress; the relevant crustal movements are supposed to be Caledonian or Variscan (Sorgenfrei \& Buch).

The Monograptus crispus zone terminates the Silurian sequence at Slagelse, whereas the boring at Nøvling passed through fossiliferous Upper Ludlowian rocks and penetrated into shale of Lower Ludlowian age with Monograptus (Colonograptus) colonus (Barrande) (Christensen 1971). Igneous rocks are lacking at Slagelse, but at Nøvling beds of volcanic origin (Basalt and Andesite) occur, and "the reddish-brown sediments between and above the igneous rocks seem to be of a composition indicating the presence of weathering products from the igneous rocks". Accordingly, "some of this volcanic activity may have occurred contemporaneously with the sedimentation of the Colonus Shale" (Christensen 1971).

After the deposition of the Lower Silurian at Slagelse followed a very long period total of regression, corresponding to the Middle and Upper Silurian, Devonian, Carboniferous, Lower Permian, and part of Upper Permian.

The dark red, silty, non calcareous claystone, which rests upon the Upper Llandovery, probably represents the Lower Permian (Rotliegendes). The red colour of the sediments and the presence of numerous small druses of selenite are suggestive of arid conditions during the deposition of these continental sediments.

The succeeding grey dolomite and shale contain gymnosperm pollen; a species of the genus Lueckisporites Potonié \& Klaus is absolutely predominant, and, accordingly, these strata must be referred to the Upper Permian (Zechstein). The strata are devoid of marine fossils, but, in addition to the above-mentioned pollen, they contain a remarkable flora which is composed exclusively of hepatics. The leaves of these plants, which occur in abundance, indicate the presence of two genera and three species of hepatics. 
It is quite evident that this flora represents a new, hitherto unknown Upper Permian biotope, indicating that the arid conditions, which contributed to the formation of the immense Zechstein evaporites, followed after a period of rather humid climate, favoring a vigorous growth of hepatics.

The precipitation of $329 \mathrm{~m}$. Zechstein evaporites terminates the Palaeozoic development in the Slagelse region. The writer has not studied material from this part of the Zechstein; the reader is therefore referred to the description and discussion in Sorgenfrei \& Buch's paper of 1964. 


\title{
Dansk sammendrag
}

\author{
Yderligere bidrag til kendskabet til palæozoikum i Slagelse no. 1, \\ Vestsjælland
}

Materialet, som danner grundlaget for den foreliggende afhandling, stammer fra en dybdeboring i nærheden af Slagelse. Boringen, der betegnes som Slagelse no. 1 (D. G. U. arkiv no. 215.257), nåede ned til en dybde af 2972 m. under terrænkoten. Boreprofilet er i sin helhed kortfattet beskrevet af Sorgenfrei \& Buch (1964). De nederste af de gennemborede lag har kunnet henføres til nedre Kambrium (C. Poulsen 1969).

I den foreliggende afhandling behandles lagserien mellem nedre Kambrium og de $\emptyset$ vre-permiske saltaflejringer. Denne lagserie har følgende opbygning: Nederst alunskifer med ganske få ubestemmelige fossilfragmenter; aflejringen er sandsynligvis $\varnothing v$ re-kambrisk, men muligheden af, at den nederste del er mellemkambrisk og den $\varnothing$ verste del nedre-ordovicisk kan ikke helt udelukkes; alunskiferen overlejres af en serie alternerende skifer og siltsten med graptoliter (tabel 1-2, p. 9 og 11), som viser, at disse sedimenter er af nedre-silurisk alder; foruden graptoliterne indeholder den nedre-siluriske lagserie et stort materiale af framboidal pyrit, som har muliggjort adskillige nye iagttagelser, af hvilke nogle kunne tyde på, at denne ejendommelige pyritform måske skal fortolkes som pyritiserede primitive alger; det nedre Silur overlejres af $r \phi \mathrm{d}$, finsandet, fossilfri lersten, som muligvis skal henføres til nedre Perm (Rotliegendes); den фverste del af den behandlede lagserie består af grå dolomit alternerende med tyndt kløvende lerskifer, der begge indeholder planterester, ved hjælp af hvilke alderen kan bestemmes til $\emptyset$ vre Perm (Zechstein).

Som det fremgår af ovenstående fakta, er den palæozoiske del af lagserien ved Slagelse meget ufuldstændig, idet i hvert fald størstedelen af Ordovicium, mellemste og $\emptyset$ vre Silur, Devon og Karbon mangler.

Boringer langs siderne af Ringkøbing-Fyn horsten har givet resultater, som tyder på, at man må regne med tilstedeværelsen af et tektonisk blokmønster, i hvilket selvstændige bevægelser af de enkelte blokke har kunnet finde sted.

Det siluriske fossilmateriale indeholder krybespor, fragmenter af brachiopoder, eurypterider, asteroider og graptoliter; blandt de sidstnævnte er der fundet en ny art af slægten Monograptus og to nye arter af slægten Dictyonema; endvidere er der fundet et par vertebratskæl. 
I Zechsteinlagene er der ikke fundet et eneste marint fossil; disse lag indeholder derimod en slægts- og artsfattig mikroflora, i hvilken en ny art af formslægten Lueckisporites er dominerende, samt en makroflora, der er ejendommelig ved kun at bestå af hepaticopsider; denne levermosflora er ligeledes slægts- og artsfattig, idet der kun synes at foreligge en ny art af slægten Jungermannites og to nye arter af en ny slægt, Gessella.

Slagelsesområdets palæogeografi og geologiske udvikling har i palæozoisk tid været betinget af Ringk $\varnothing$ bing-Fyn horstens funktion som det danske sænkningsområdes sydvestlige kystlinie og tillige af lokale brudtektoniske bevægelser. De palæozoiske sedimenter er ikke stærkt omdannede; dette gælder især de permiske aflejringer; de ældre palæozoiske sedimenter viser derimod tydelige spor af tektonisk stress i form af talrige småforkastninger og glideflader, der ligesom lagenes hældning kan skyldes caledoniske eller variskiske jordskorpebevægelser (Sorgenfrei \& Buch 1964). 


\section{References}

Balme, B. F., 1970: Palynology of Permian and Triassic Strata in the Salt Range and Surghar Range, West Pakistan. - In Kummel, B. \& Teichert, C.: Stratigraphic Boundary Problems: Permian and Triassic of West Pakistan. - Univ. of Kansas, Department of Geology: Special Publication 4.

Bars, M. S., 1967: Illustrations of Canadian Fossils: Carboniferous and Permian Spores of Canada. - Geol. Surv. Canada, Department of Energy, Mines, and Resources, Paper 67.11. - Ottawa.

Bassler, R. S., 1909: Dendroid Graptolites of the Niagaran Dolomites at Hamilton, Ontario. - Smithsonian Institution: U. S. National Museum, bull. 65. - Washington, D.C.

Bjerreskov, M., 1971: Stratigraphy of the Llandovery Series on Bornholm. - Bull. Geol. Soc. Denmark, vol. 21.1. - Copenhagen.

Bouček, B. \& Př́byl, A., 1942: Über böhmische Monograpten aus der Untergattung Streptograptus Yin. - Mitteilungen der Tschechischen Akademie der Wissenschaften, Jahrg. 52, no. 1. - Prag.

Bulman, O. M. B., 1927: Koremagraptus, a new Dendroid Graptolite. - Ann. and Mag. Nat. Hist., ser. 9, vol. 19.

- 1927-1934: Monograph of British dendroid Graptolites, pts. 1-3. - Palaeontographical Soc. London.

- 1955: Graptolithina with Sections on Enteropneusta and Pterobranchia. - Treatise on Invertebrate Paleontology, edited by Raymond C. Moore, pt. 5. - Univ. of Kansas Press.

Christensen, O. Bruun, 1971: Øvre Silur i dybdeboringen Nøvling no. 1 i Midtjylland. - Danmarks Geologiske Undersøgelse, Rapport no. 7. - Copenhagen.

Elles, G. L. \& Wood, E. M. R., 1901-1918: Monograph of British Graptolites. - Palaeontographical Soc. London.

Franke, D., 1967: Der erste Aufschluss im tieferem Paläozoikum Norddeutschlands und seine Bedeutung für die tektonische Gliederung Mitteleuropas. - Jahrb. für Geologie, 1. - Berlin 1965.

Jaeger, H., 1967: Ordoviz auf Rügen. Datierung und Vergleich mit anderen Gebieten. Berichte d. deutsch. Ges. geol. Wiss., A: Geol. Paläont., 12. 1/2. - Berlin.

Lapworth, C., 1873: On an improved classification of the Rhabdophora. - Geol. Mag., vol. 5. - London.

- 1876: On Scottish Monograptidae. - Geol. Mag., new ser., dec. 2, vol. 3. - London.

Laursen, D., 1940: Cyrtograptusskifrene paa Bornholm, 1, Øleå. - Danmarks Geologiske Undersøgelse, 2nd. ser., no. 64. - Copenhagen.

Love, L. G., 1958: Micro-organisms and the presence of syngenitic pyrite. - Quart. Journ. Geol. Soc. London, vol. 113, pt. 4.

- 1962: Further studies on micro-organisms and the presence of syngenetic pyrite. Palaeontology, vol. 6. 
- 1962a: Pyrite spheres in sediments. - In Jensen, M. L. (ed.): The biochemical cycle of the sulfur isotopes. - New Haven, Yale University Press.

- 1963: The composition of Pyritosphaera barbaria Love. - Palaeontology 6.

- \& Murray, J. W., 1963: Biogenetic pyrite in recent sediments of Christchurch Harbour, England. - Am. Journ. Sci., vol. 261.

- \& Amstutz, G. C., 1966: Review of microscopic pyrite from the Devonian Chattanooga Shale and Rammelsberg Banderz. - Fortschritte der Mineralogie, vol. 43.

Perner, J., 1897: Études sur les graptolites de Bohême, pt. 3. - Leipzig et Prague.

Potonié, R., 1956-1970: Synopsis der Gattungen der Sporae dispersae 1-5. - Beihefte zum Geol. Jahrb. 23, 31, 39, 72, 87. - Hannover.

Poulsen, C., 1969: The Lower Cambrian from Slagelse no. 1, Western Sealand. - Danmarks Geologiske Undersøgelse, 2. Række, no. 93. - Copenhagen.

Přibyl, A., 1948: Bibliographic Index of Bohemian Silurian Graptolites. - Praha.

Rickards, R. B., 1970: The Llandovery (Silurian) graptolites of the Howgill Fells, Northern England. - Palaeontographical Soc. London.

Ruedemann, R., 1947: Graptolites of North America. - Geol. Soc. America, mem 19. Baltimore, MD.

Schopf, J. W. \& Blacic, J. M., 1971: New Microorganisms from the Bitter Springs Formation (Late Precambrian) of the North-Central Amadeus Basin, Australia. - Journ. of Paleontology, vol. 45. - Tulsa.

Schuster, R. M., 1966-1969: The Hepaticae and Antocerotae of North America East of the hundredth meridian. - New York and London.

Sorgenfrei, T. \& Buch, A., 1964: Deep Tests in Denmark 1935-1959. - Danmarks Geologiske Undersøgelse, 3. Række, no. 36. - Copenhagen.

Tullberg, S. A., 1882-1883: Skånes Graptoliter. - Sveriges Geologiska Undersökning, ser. C, no. 50. - Stockholm.

Törnquist, S. L., 1899: Monograptidae of the Scanian Rastrites beds. - Lunds Universitets Årsskrift, vol. 2. - Lund.

- 1912: Graptolitologiska Bidrag 8-10. - Geologiska Föreningens i Stockholm Förhandlingar, vol. 34. - Stockholm.

Urbanek, A., 1958: Monograptidae from erratic boulders of Poland. - Palaeontologia polonica, no. 9. - Warzawa.

Vallentyne, J. R., 1962: Concerning Love, microfossils and pyrite spherules. - Trans. New Yor Acad. Sci., ser. 2, vol. 25, no. 2.

- 1962a: A chemical study of pyrite spherules isolated from sediments of Little Round Lake, Ontario. - In Jensen, M. L. (ed.): The biochemical cycle of the sulfur isotopes. - New Haven, Yale Univ. Press.

, - \& Swabey, Y. S., 1955: A reinvestigation of the history of Lower Linsley Pond. American Journ. Sci., vol. 253. 
Plates 
Plate 1

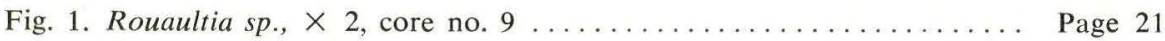

- 2. Dictyonema danicum n. sp., holotype, $\times 1$, core no. $8 \ldots \ldots \ldots \ldots-13$

- 3. Koremagraptus onniensis Bulman?, $\times 1$, core no. $8 \ldots \ldots \ldots \ldots$ - 15

- 4. Eurypterus? sp., segment of mesosoma, $\times 5$, core no. $9 \ldots \ldots \ldots \ldots$ - 13

- 5. Marginals of asteroid, $\times 5$, core no. $7 \ldots \ldots \ldots \ldots \ldots \ldots \ldots \ldots \ldots$

- 6. Framboidal pyrite (superframboids), $\times 6$, core no. $10 \ldots \ldots \ldots \ldots .25$

- 7. Fragmentary superframboid, showing framboids to the left and sediment matrix to the right, $\times 100$, core no. $10 \ldots \ldots \ldots \ldots \ldots \ldots \ldots$

- 8-9. Black phosphorite pebbles in shale, $\times 1$, core no. $9 \ldots \ldots \ldots \ldots .8$ 


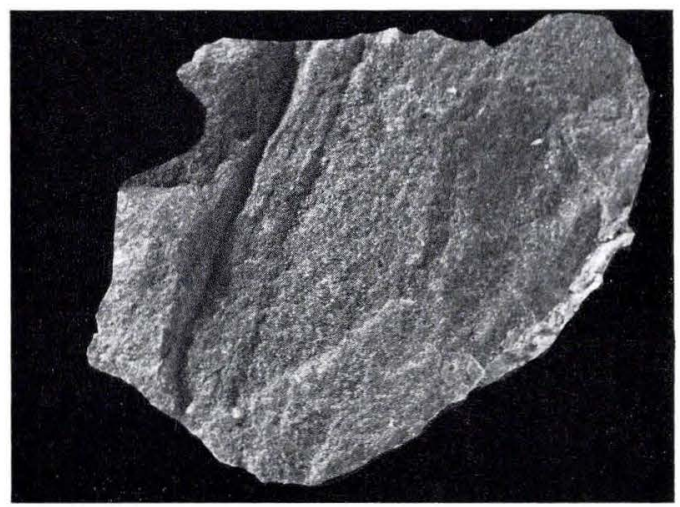

1

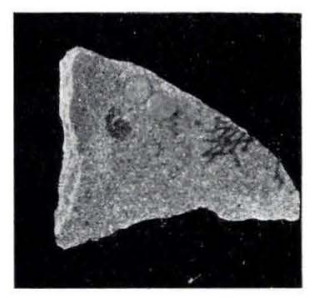

3

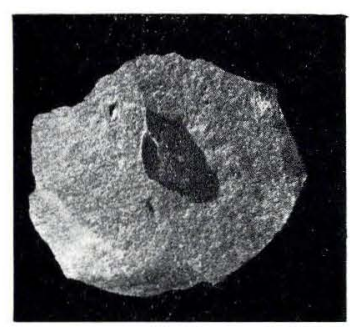

8

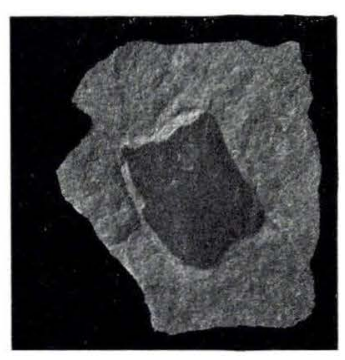

9

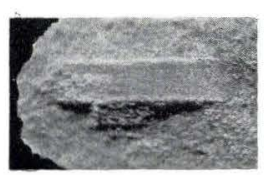

4

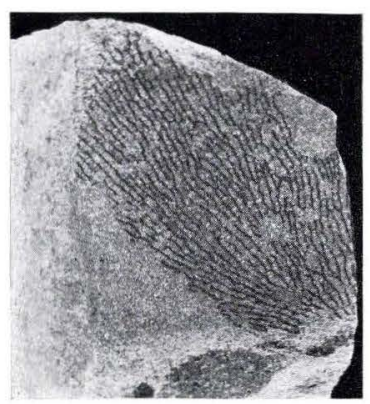

2

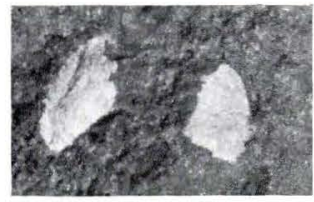

5

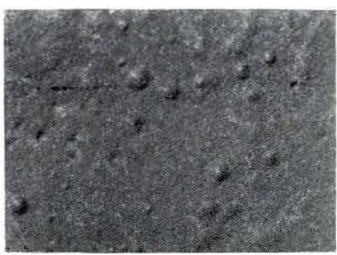

6

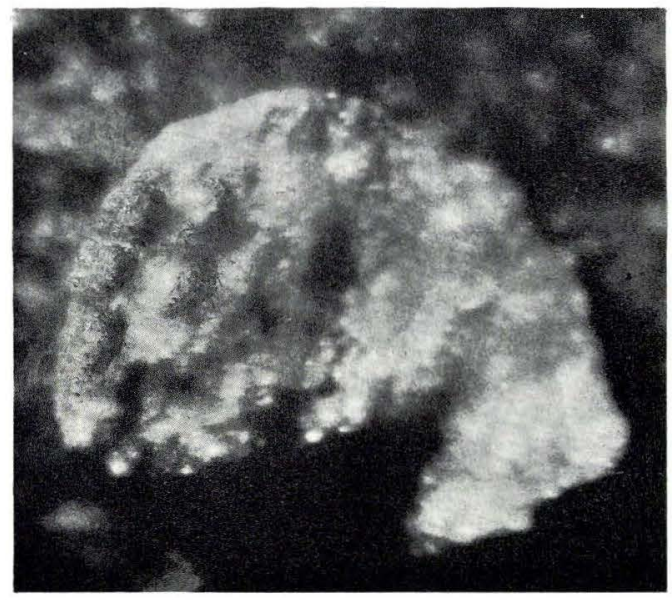

7

4 D.G.U. II. rk. nr. 101 
Plate 2

Dictyonema danicum n. sp., holotype, $\times 8.5$, core no. 8 


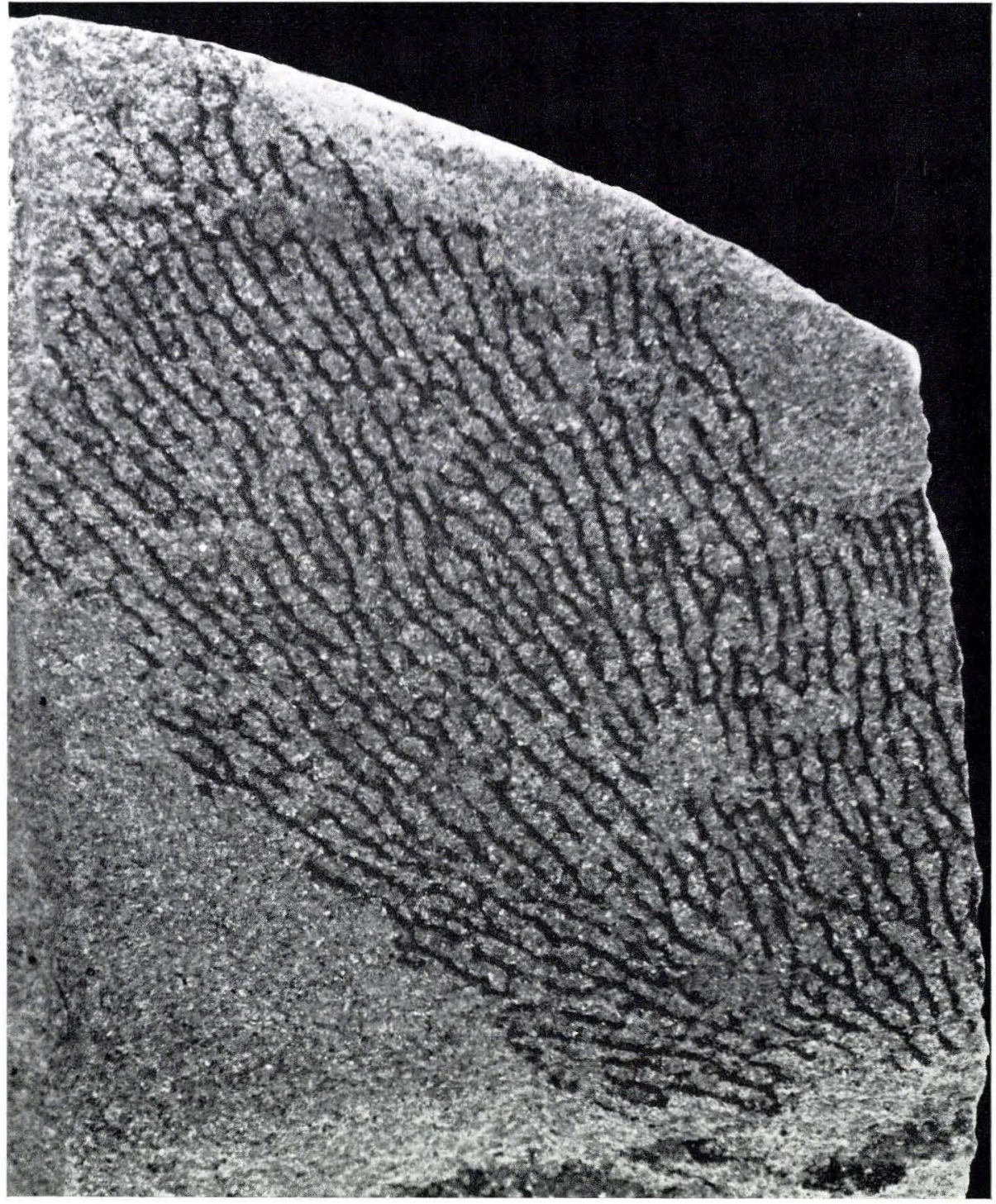


Plate 3

Dictyonema perangustum n. sp., holotype, $\times$, core no. 10 Page 14 


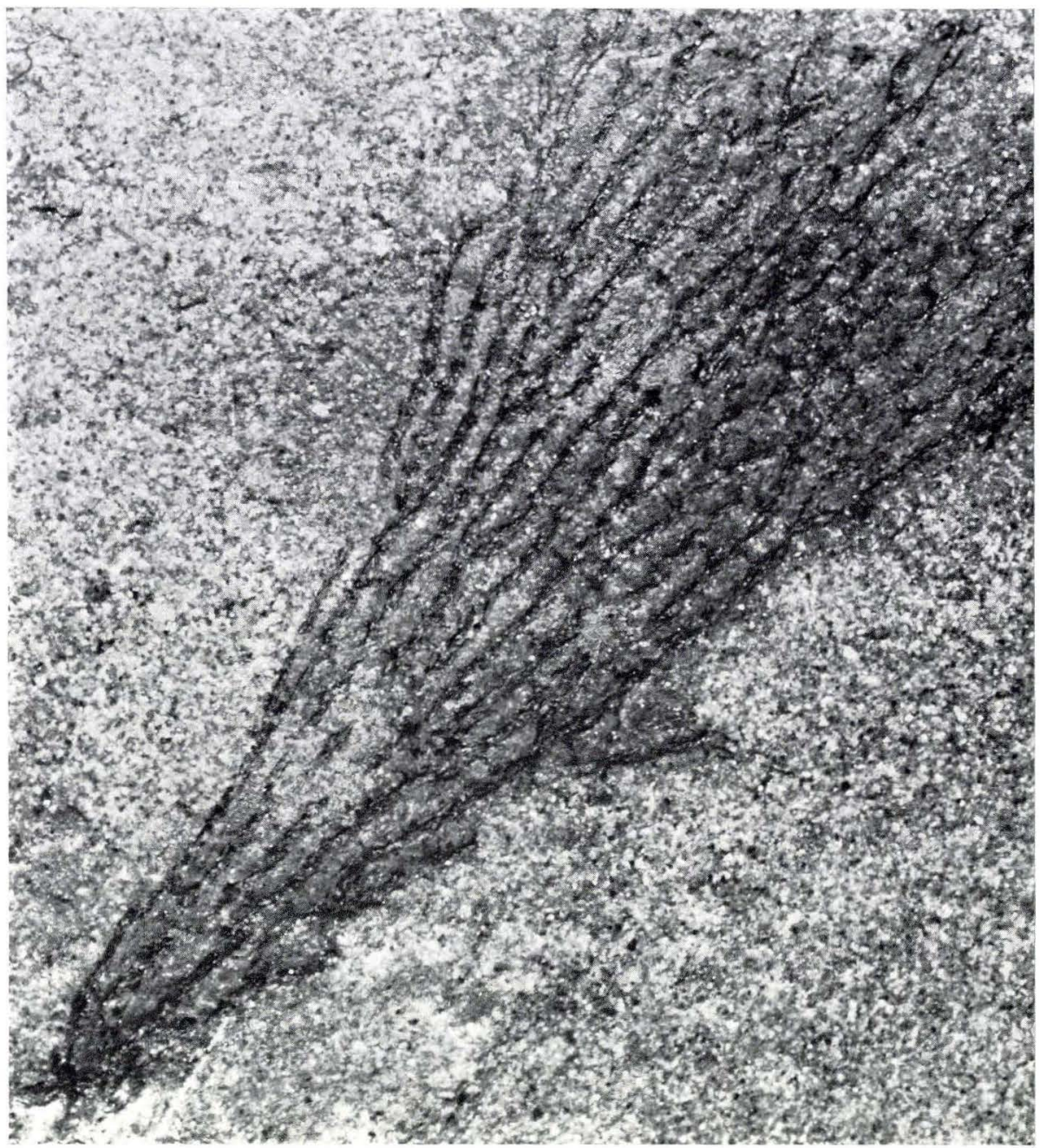


Plate 4

Fig. 1. Koremagraptus onniensis Bulman?, $\times 5$, core no. $8 \ldots \ldots \ldots$ Page 15

- 2. Retiolites geinitzianus (Barrande), $\times 5$, core no. $8 \ldots \ldots \ldots \ldots-15$

- 3. Monograptus discus Törnquist, $\times 5$, core no. $10 \ldots \ldots \ldots \ldots \ldots$ - 16

- 4. Monograptus exiguus exiguus (Nicholson), $\times 5$, core no. $10 \ldots \ldots$ - 17

- 5. Monograptus selandicus n. sp., holotype, $\times 5$, core no. $9 \ldots \ldots \ldots \ldots$ - 19

- 6. Monograptus nudus nudus (Lapworth), $\times 5$, core no. $9 \ldots \ldots \ldots \ldots$. 18

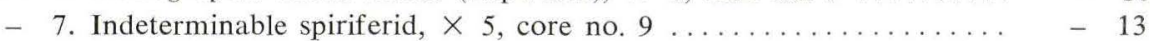

- 8. Vertebrate scale no. $1, \times 15$, core no. $7 \ldots \ldots \ldots \ldots \ldots \ldots \ldots \ldots$ - 20

- 9. Vertebrate scale no. $2, \times$ about 100 , core no. $9 \ldots \ldots \ldots \ldots \ldots \ldots$ - 21

- 10. Phosphorite pebble with braciopod fragment (orthid?), $\times 5$, core no. 9 


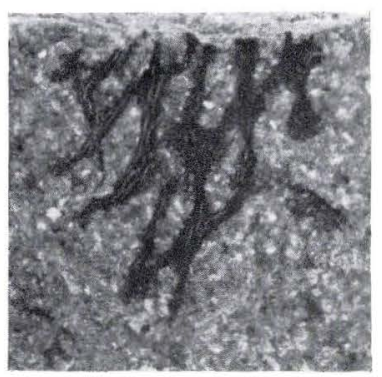

1

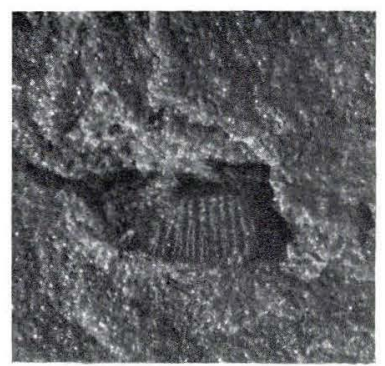

10

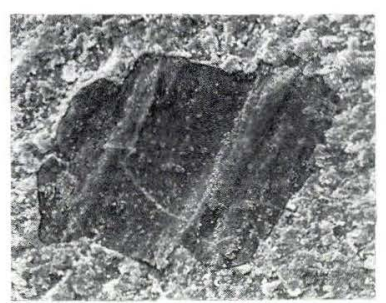

9

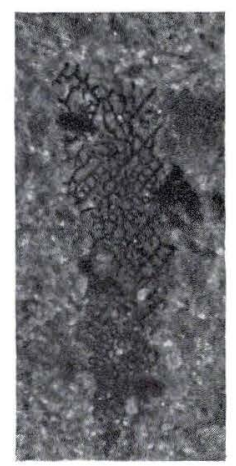

2

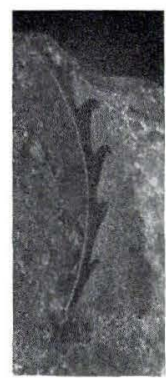

5

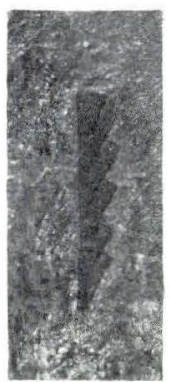

6

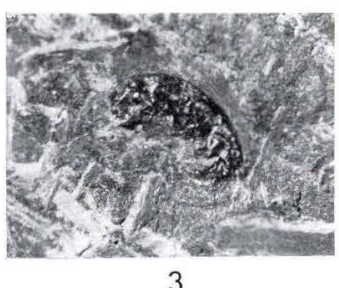

3

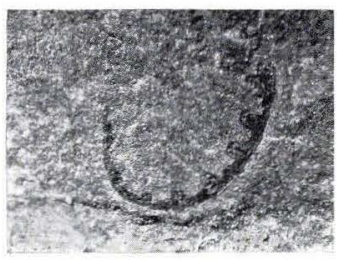

4

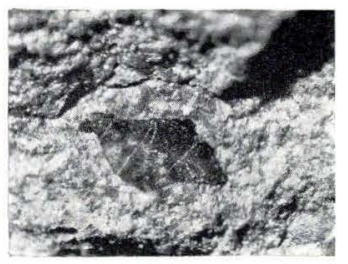

8

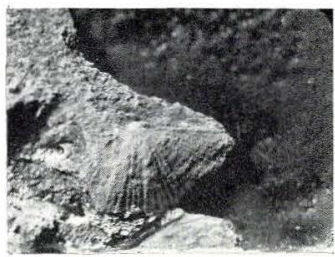

7 
Plate 5

Fig. 1. Superframboid with small framboids from wash material between

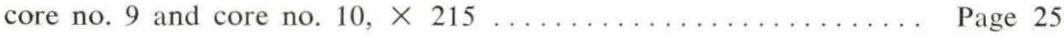

- 2. Part of the same, $\times 540$. 

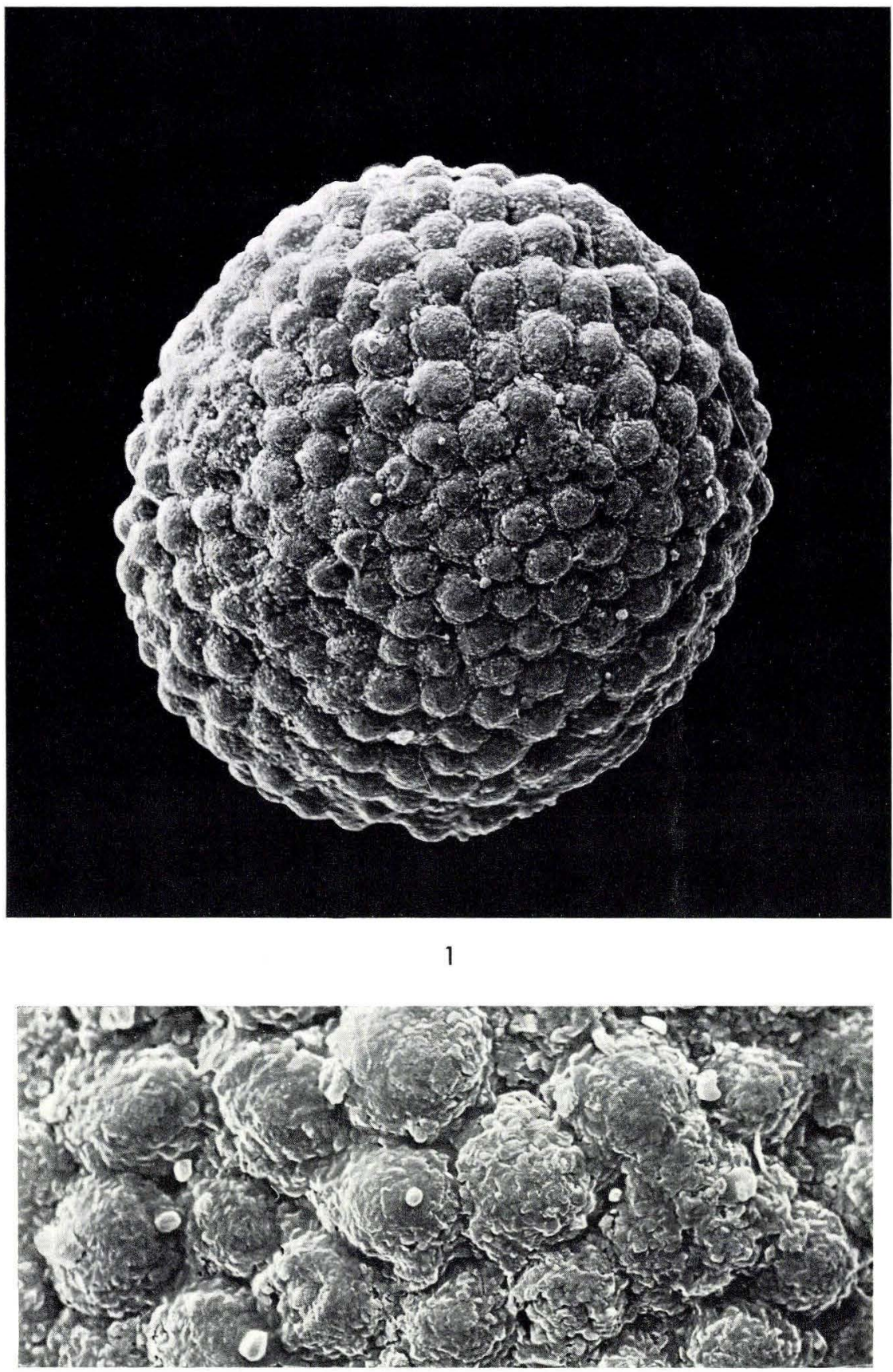
Plate 6

Fig. 1. Superframboid with big framboids from wash material between core no. 9 and core no. $10, \times 215$

- 2. Part of the same, $\times 540$. 

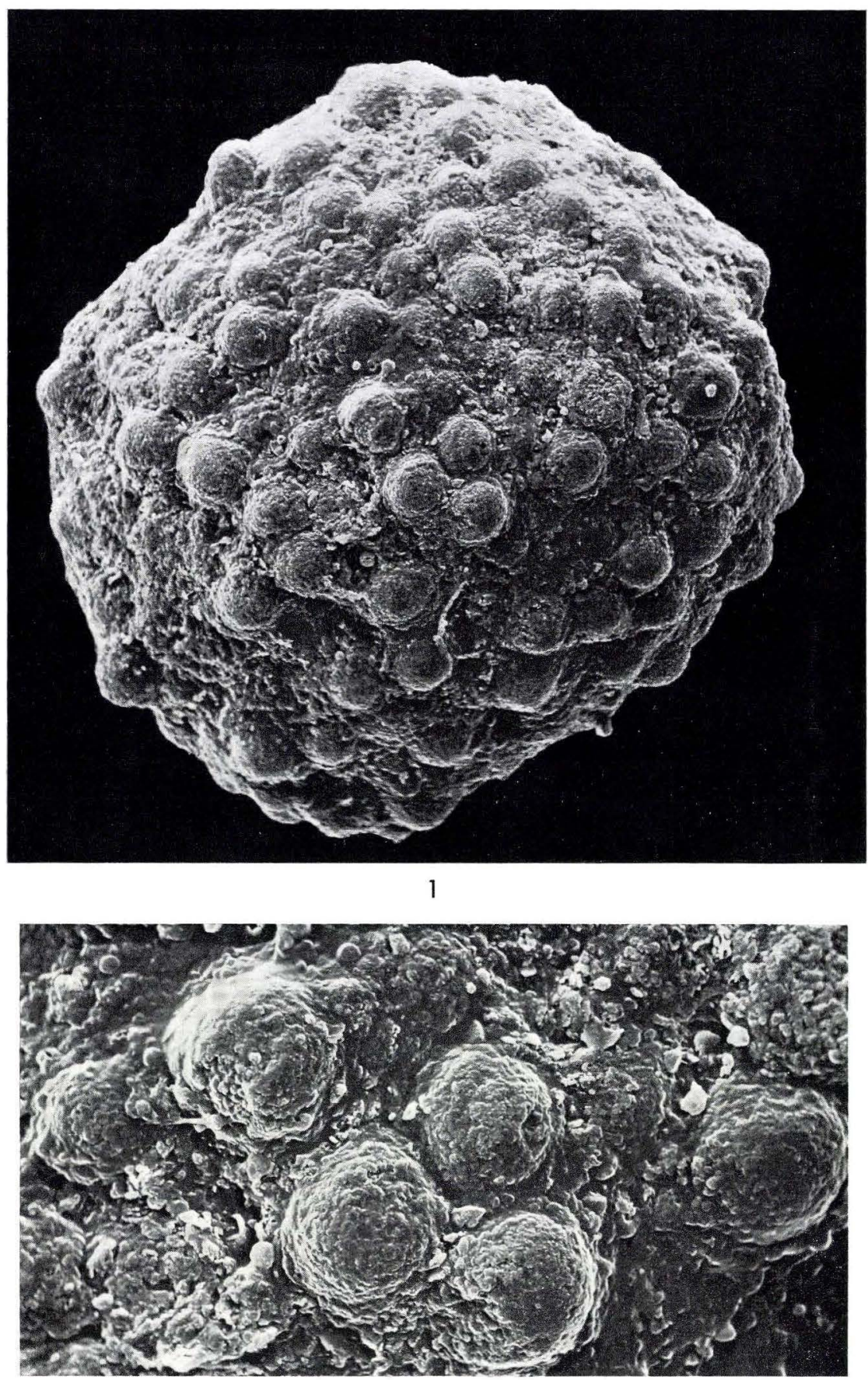
Plate 7

Fig. 1. Polished section of Silurian rock (core no. 9, giving a good idea of

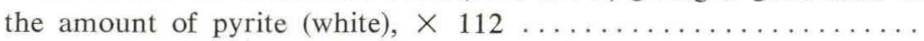

- 2. Portion of the same section, showing that the greater part of the pyrite occurs in the shape of spherules, $\times 224 \ldots \ldots \ldots \ldots \ldots \ldots-2$ 

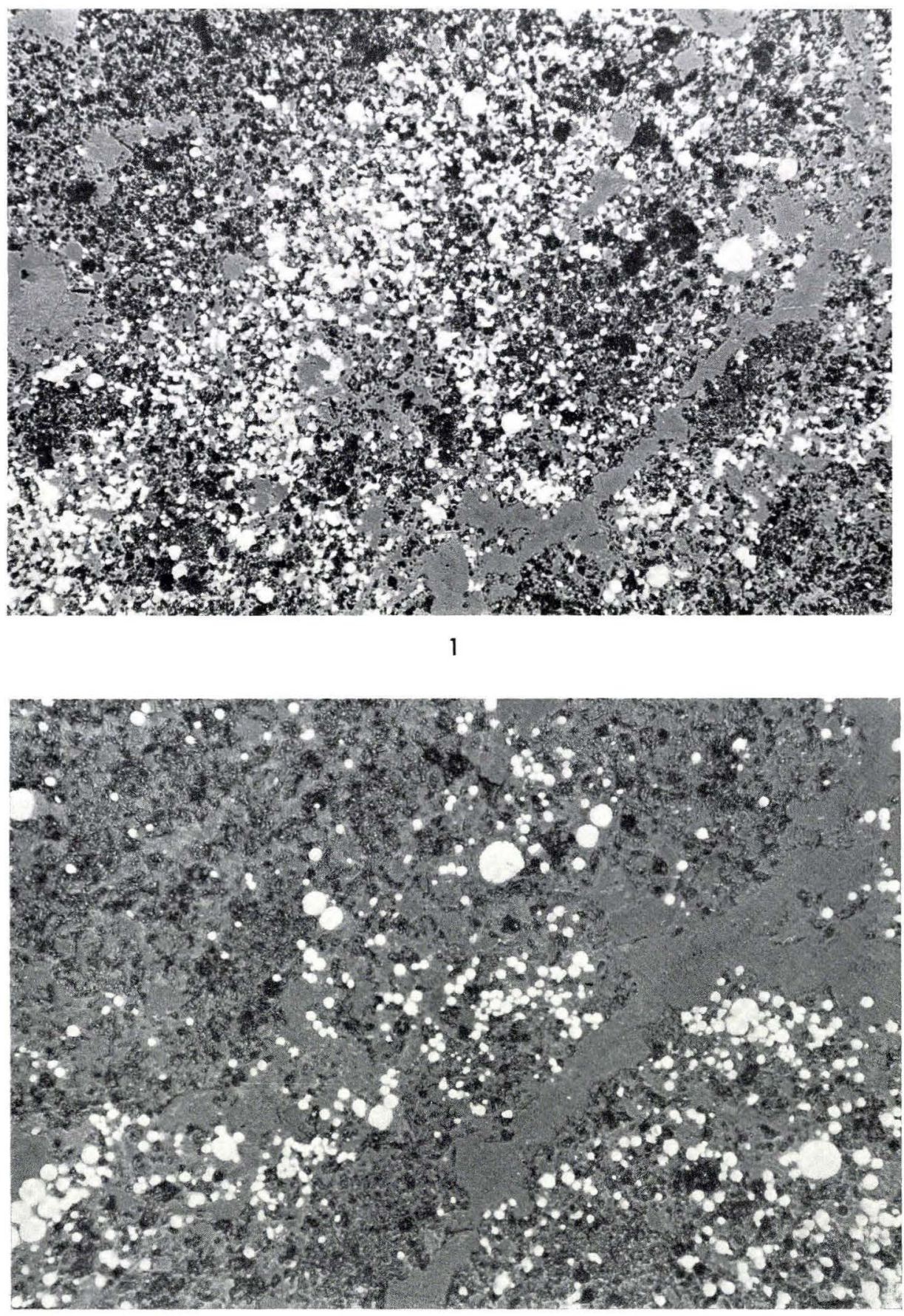
Plate 8

Fig. 1. Polished section of Silurian rock (core no. 10), showing two

superframboids of different sizes, $\times 224 \ldots \ldots \ldots \ldots \ldots \ldots \ldots$
- 2. Part of the same section, showing a couple of framboids and a spheric microorganism(?) apparently in an early stage of pyritization, $\times 2240$ 


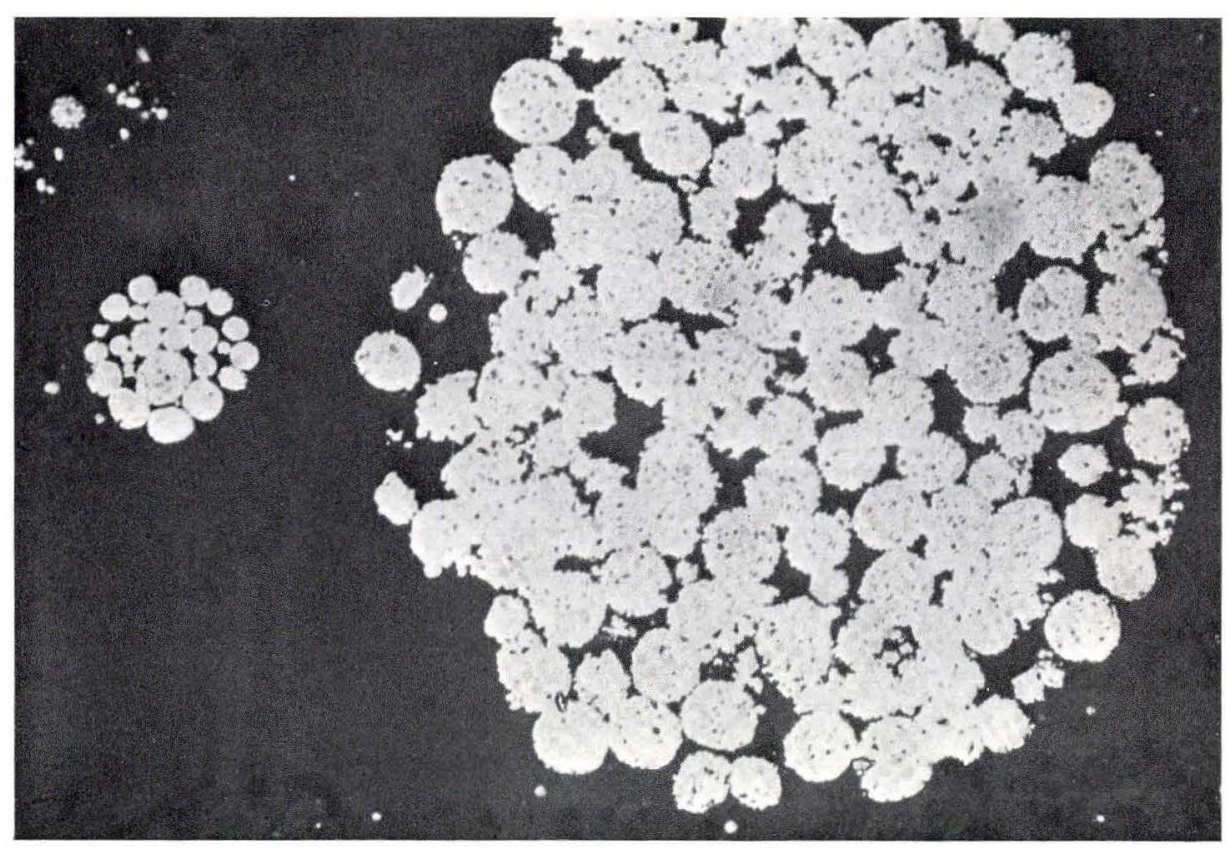

1

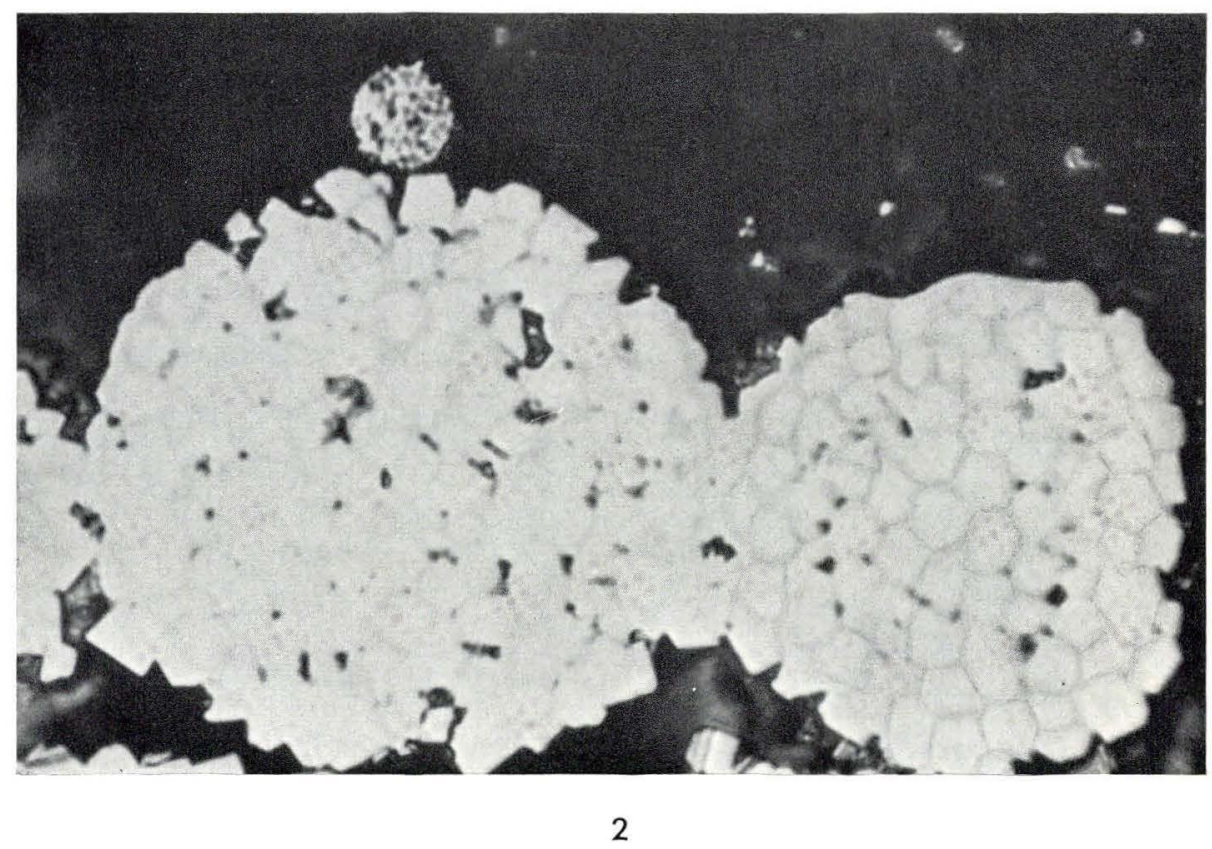


Plate 9

Fig. 1. Matrix body of superframboid from wash material between core no. 9 and core no. 10, consisting of quartz, showing the cavities in which the framboids were situated, $\times 273 \ldots \ldots \ldots \ldots \ldots \ldots \ldots$

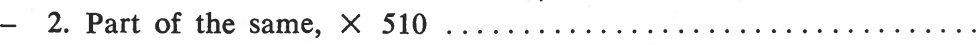




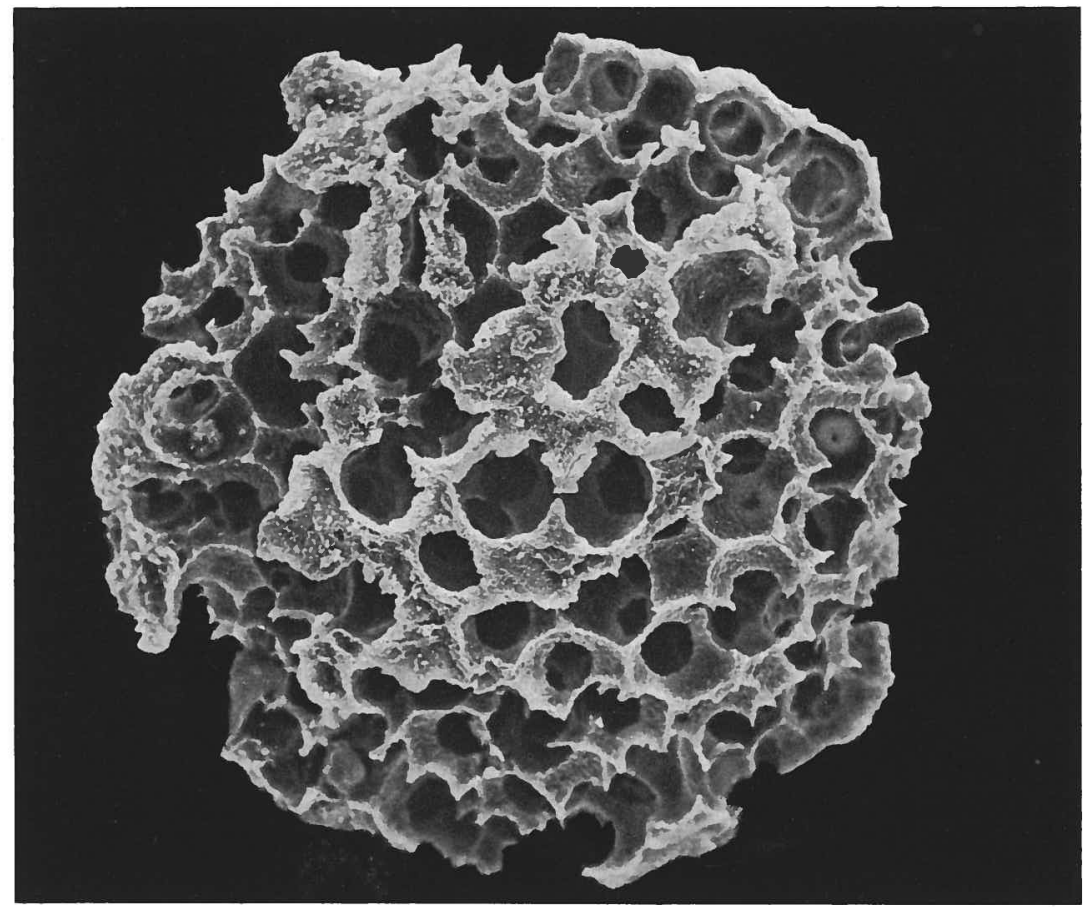

1

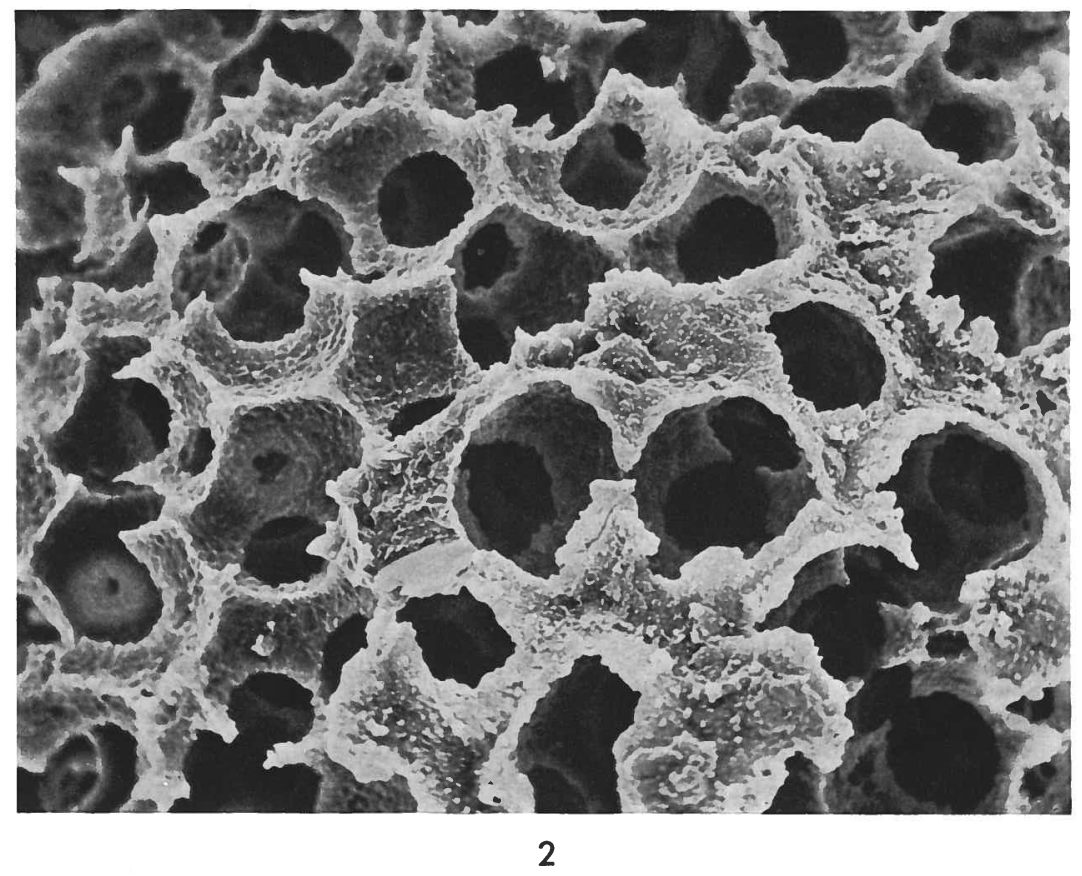

5 D.G.U. II. rk. nr. 101 
Plate 10

Fig. 1. Part of matrix body of superframboid (same as in pl. 9), showing natural casts of framboids and their external crystals, $\times 2220 \ldots \ldots$.

- 2. Fragmentary matrix body of superframboid from core no. 10, showing silicified spheric central bodies in the cavities in which the fram-

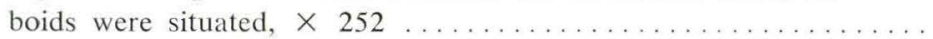




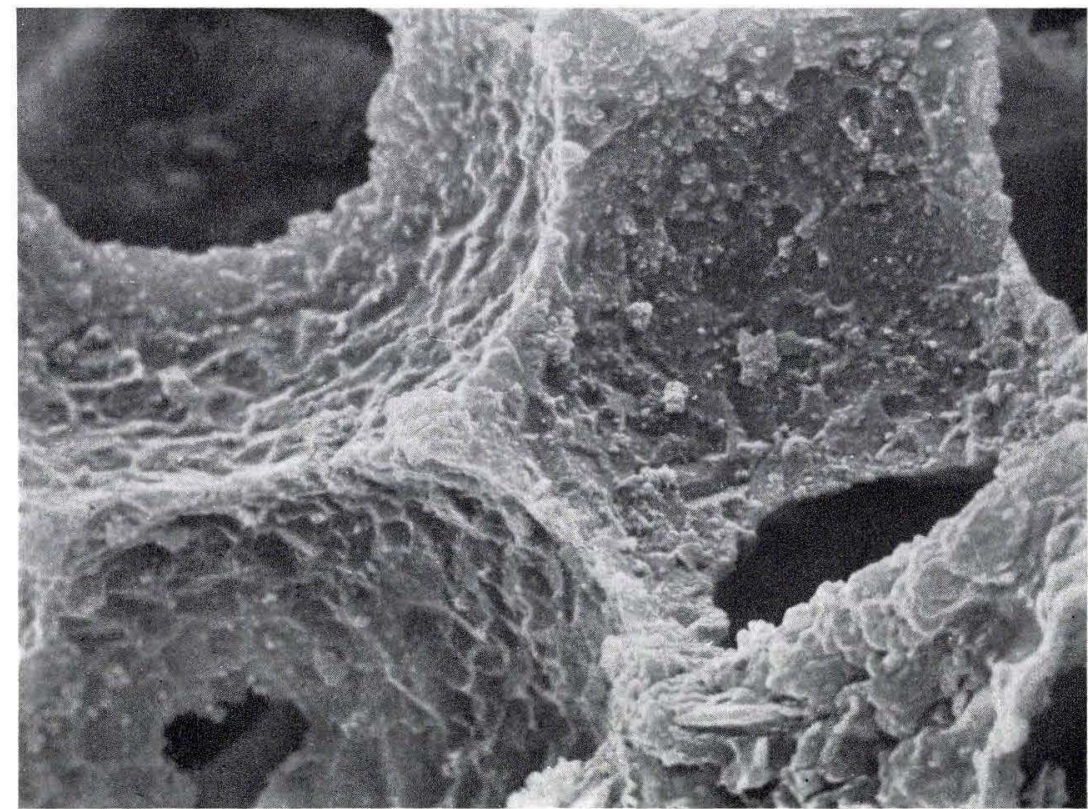

\section{1}

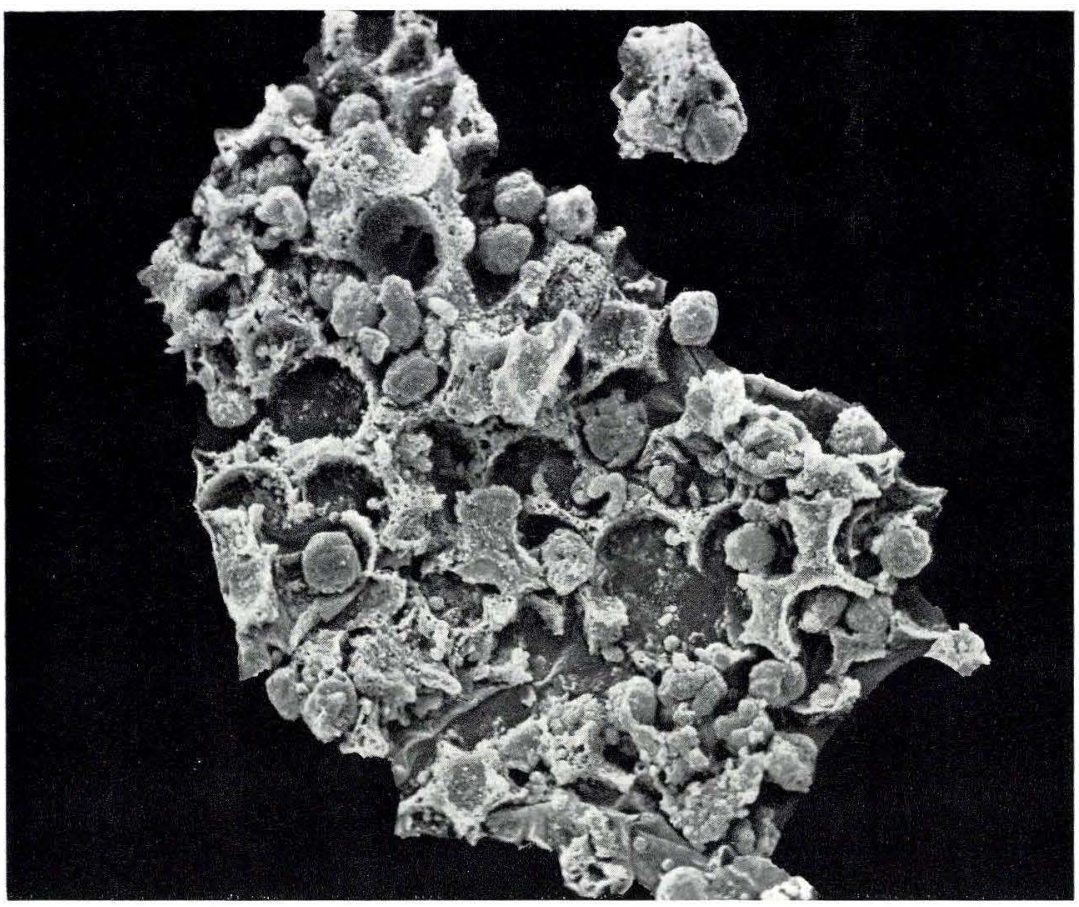


Plate 11

Figs. 1-2. Part of the matrix body of superframboid, figured as pl. 10, fig. $2, \times 1020$ and $\times 1428$ respectively $\ldots \ldots \ldots \ldots \ldots \ldots$ Page 25 


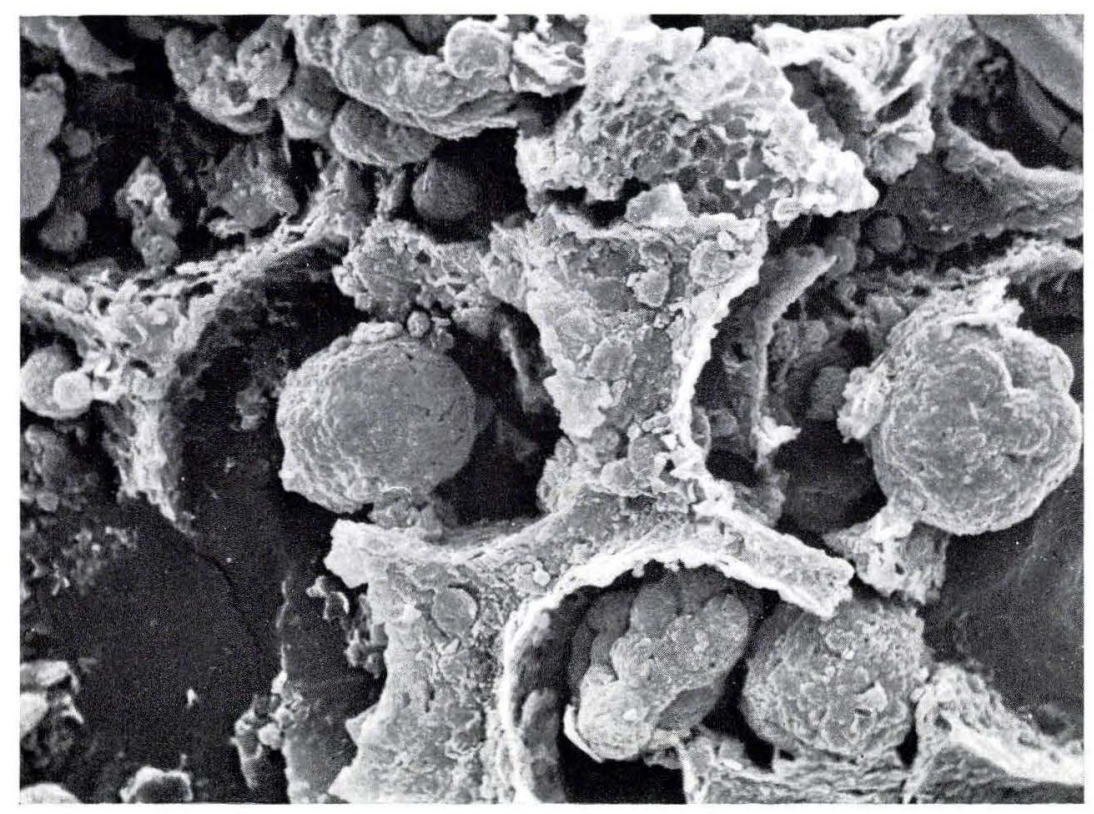

\section{1}

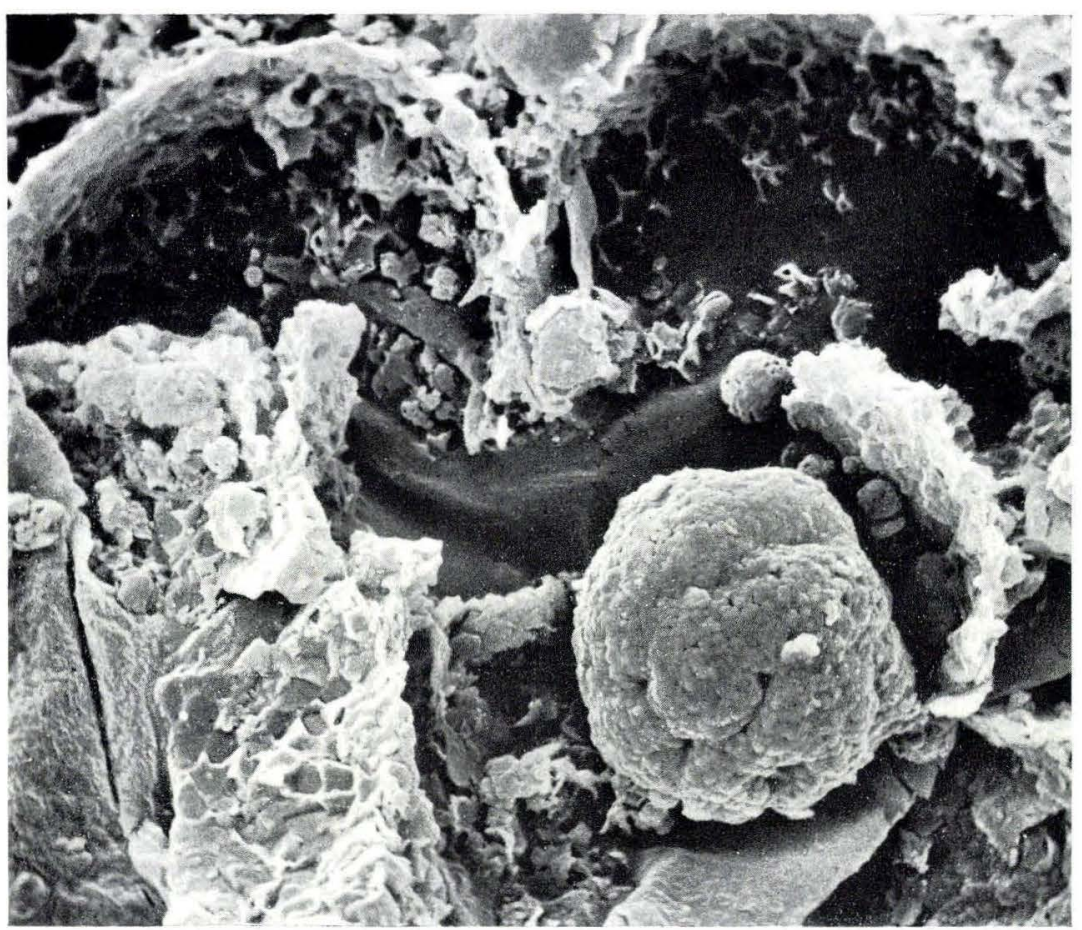


Plate 12

Fig. 1. Polished section of Silurian rock (core no. 10), showing a few isolated crystals of pyrite, numerous framboids, and a great many small, worm or sausage-shaped bodies which may possibly be the microorganisms (bacteria?) responsible for the production of hydrogen sulphide and, consequently, also concerned with the formation of pyrite, $\times 2400 \ldots \ldots \ldots \ldots \ldots \ldots \ldots \ldots \ldots \ldots \ldots$

- 2. Grey dolomite from core no. 6, showing leafy shoot of Jungermannites selandicus n. sp. (J), holotype, and leaves of Gessella communis $\mathrm{n}$. g. et $\mathrm{n}$. sp., $\times 1 \ldots \ldots \ldots \ldots \ldots \ldots \ldots \ldots \ldots \ldots \ldots \ldots$ 


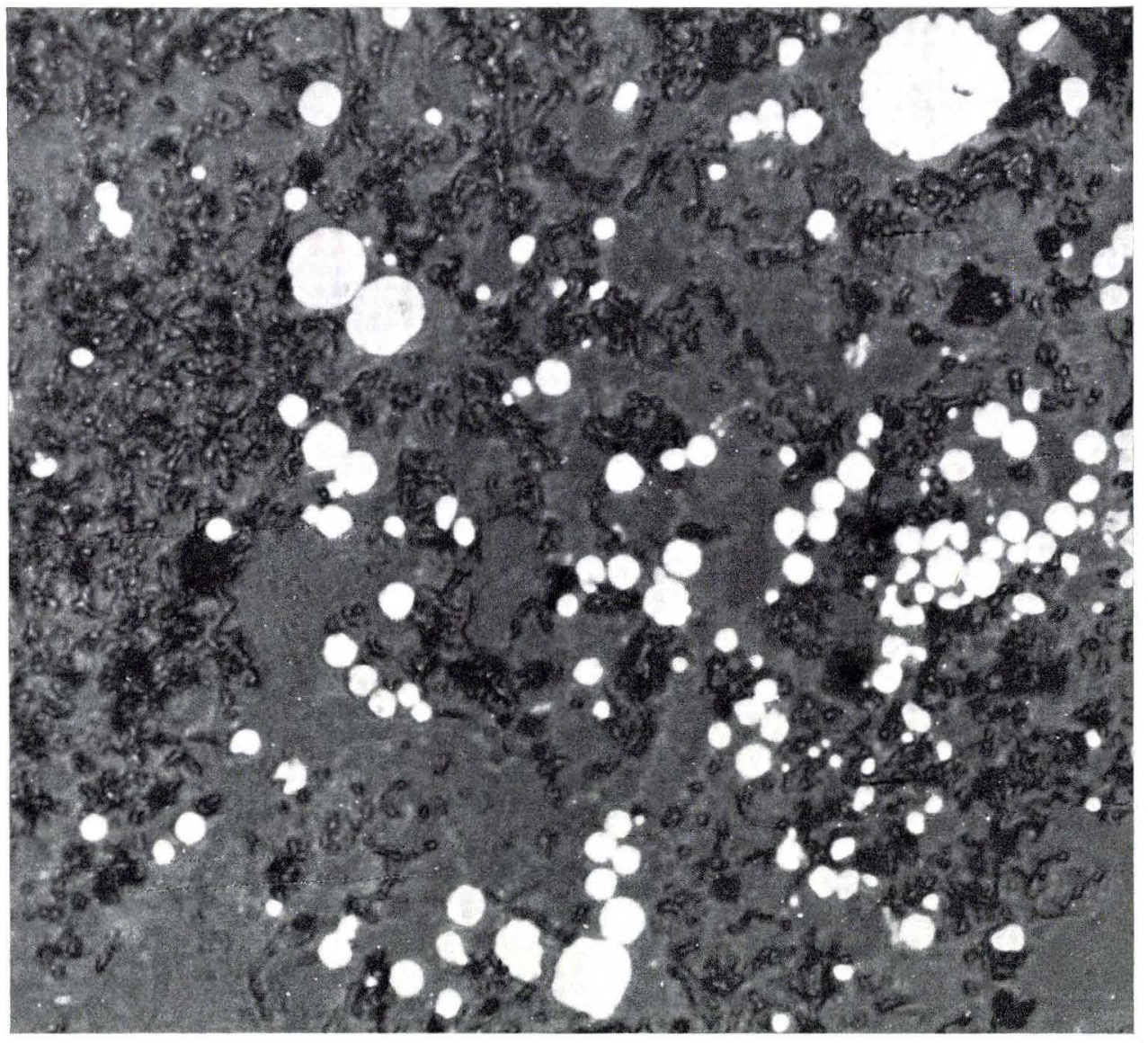

1

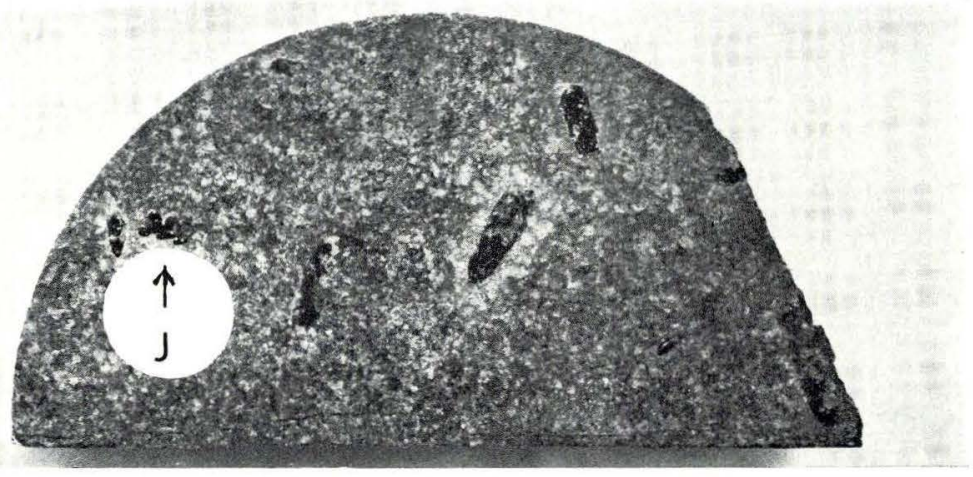


Plate 13

Fig. 1. Gessella communis n. g. et n. sp., sterile shoot, holotype, $\times 5.5$,

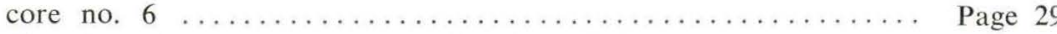

- 2. Gessella striata $\mathrm{n}$. g. et $\mathrm{n}$. sp., sterile shoot, holotype, $\times 5$, core no. 5

$-30$

- 3. Rhizome, referred to Gessella communis n. g. et n. sp., core no. 5,

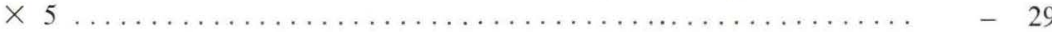




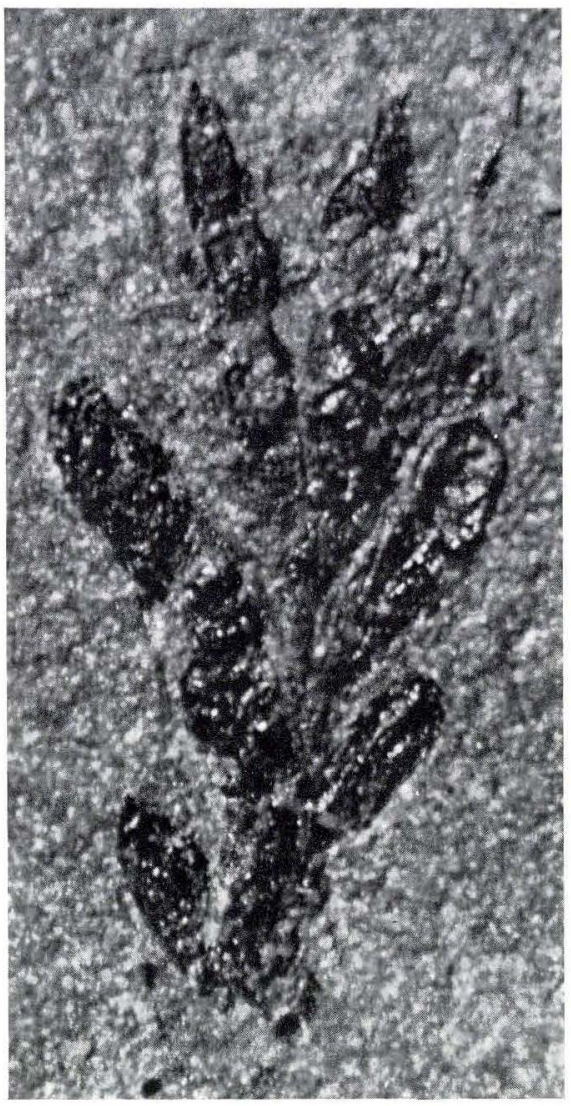

1

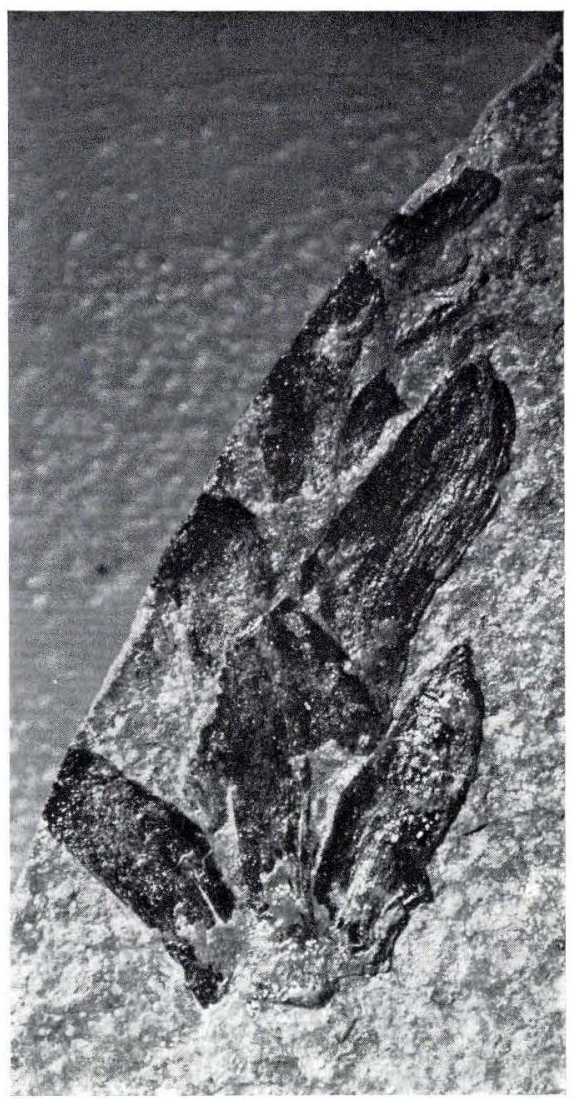

3

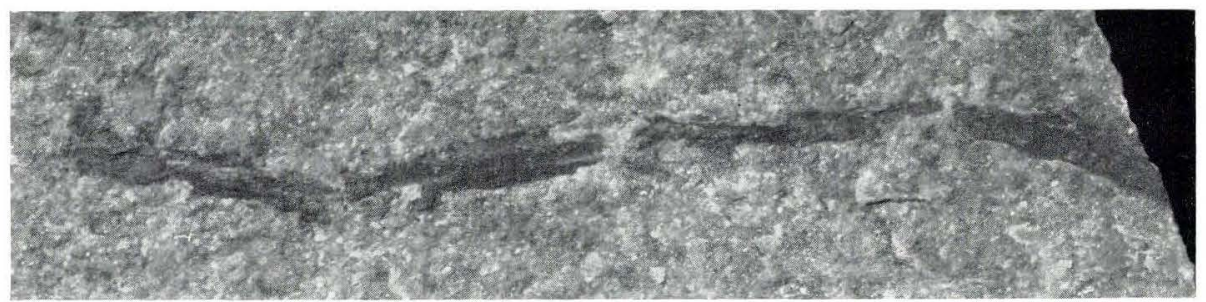


Plate 14

Fig. 1. Gessella communis n. g. et n. sp., fragment of stem with two curved

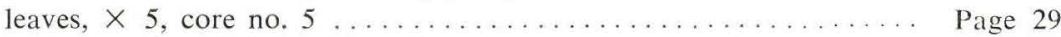

- 2. Gessella communis n. g. et n. sp., leaf, $\times 6$, core no. $5 \ldots \ldots \ldots$ - 29

- 3. Gessella communis n. g. et $\mathrm{n}$. sp., part of leaf, showing oblong

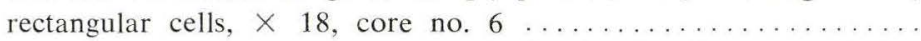

- 4. Gessella striata n. g. et n. sp., leaf, showing longitudinal striation,

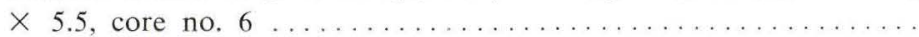

- 5. Capsule with spores, referred to Gessella communis n. g. et n. sp.,

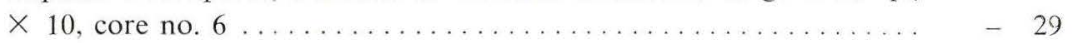

- 6. Lueckisporites parvulus n. sp., holotype, $\times 1250$, core no. $6 \ldots \ldots$ - 32 


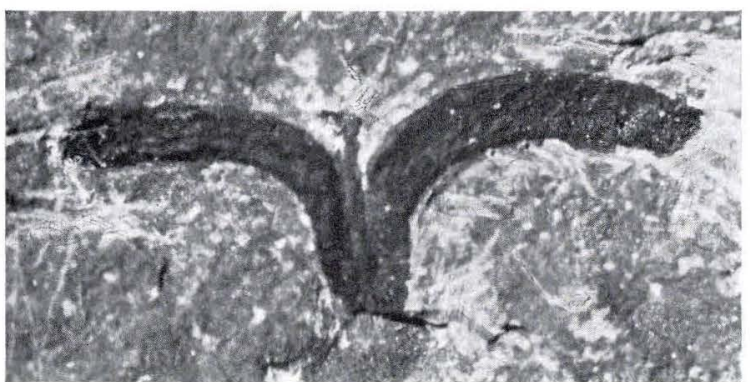

1

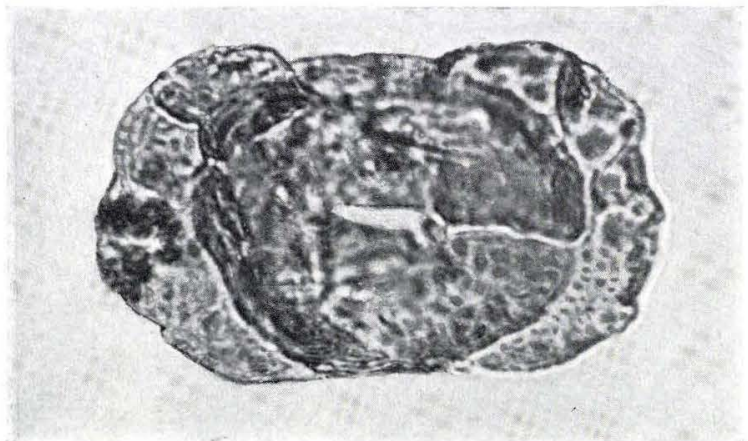

6

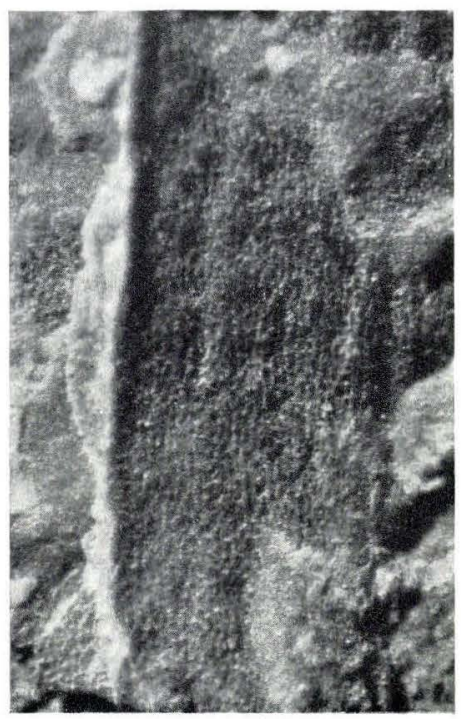

3

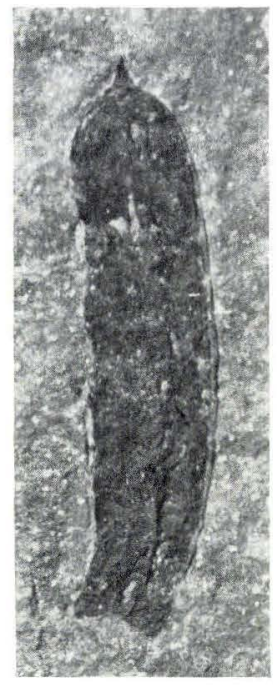

2

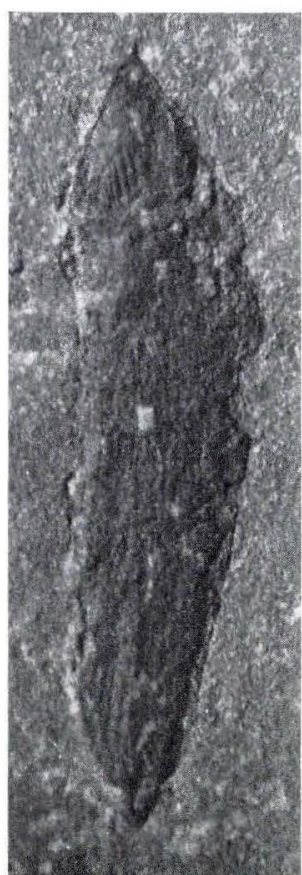

4

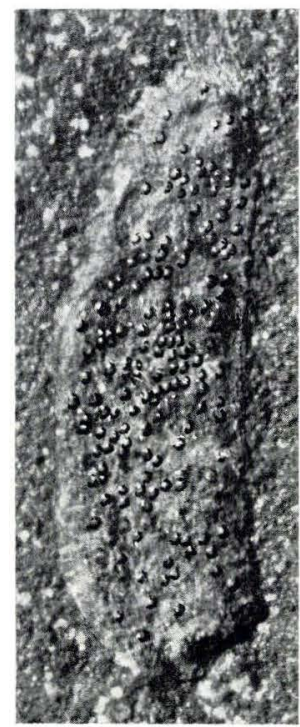

5 
Plate 15

Fig. 1. Jungermannites selandicus n. sp., holotype, shoot, showing leaves and amphigastria (?), $\times 20$, core no. $5 \ldots \ldots \ldots \ldots \ldots \ldots \ldots$

- 2. Dictyonema perangustum $\mathrm{n}$. sp., holotype, $\times 1.2$, core no. $10 \ldots \ldots$.
- 3. The same, turned in order to show the dissepiments more clearly,

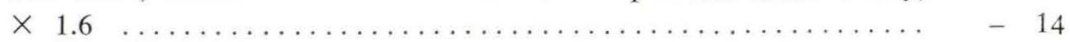

- 4. Gessella communis n. g. et n. sp., part of capsule, showing natural

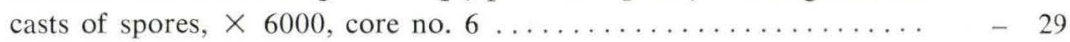

Page 31

$-14$ 


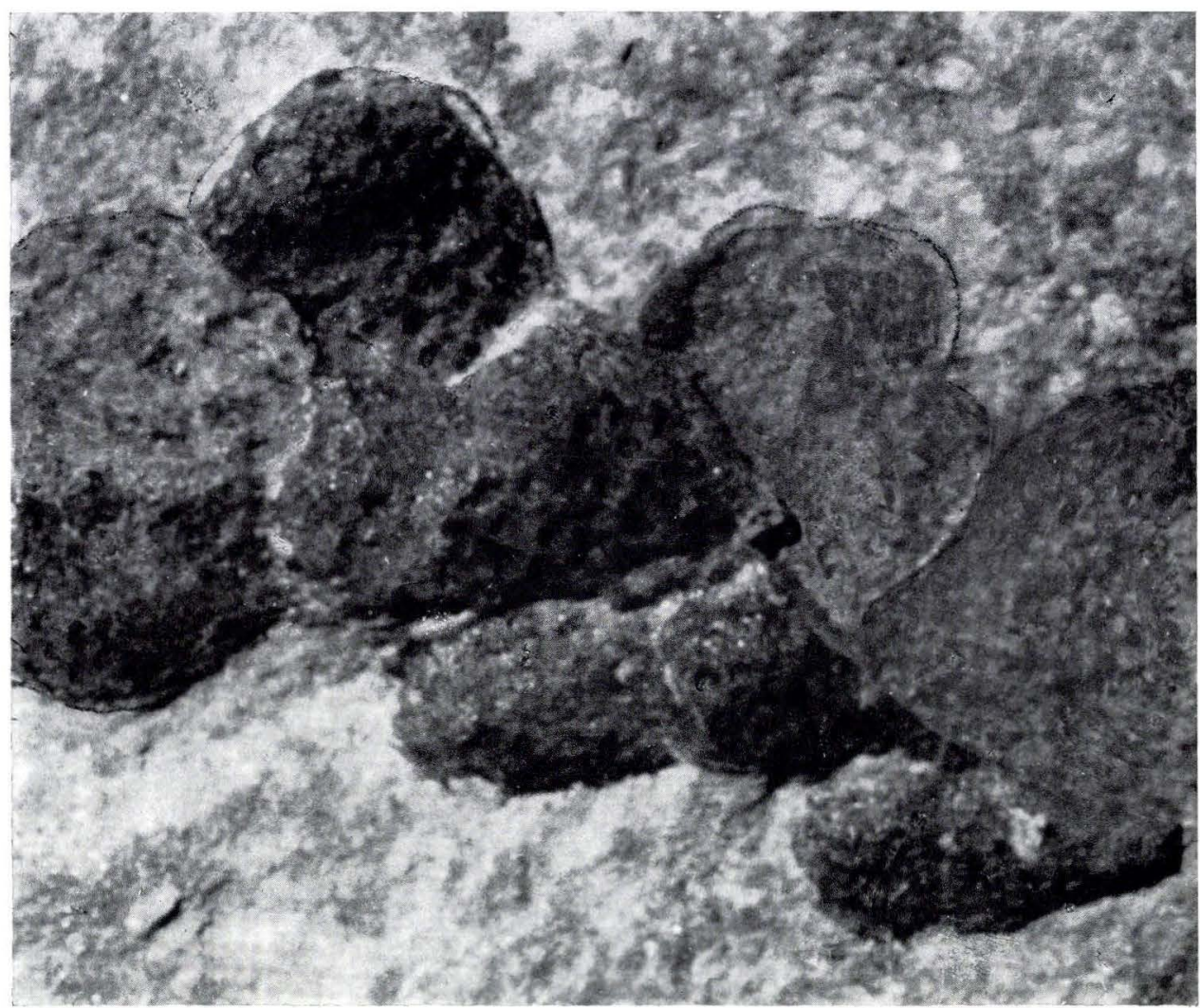

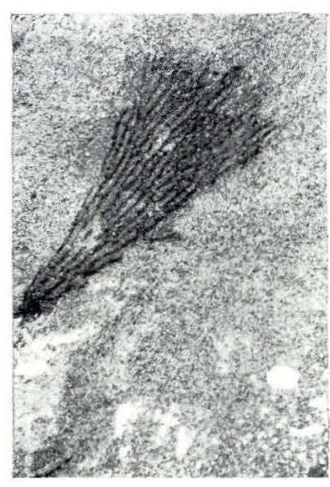

2

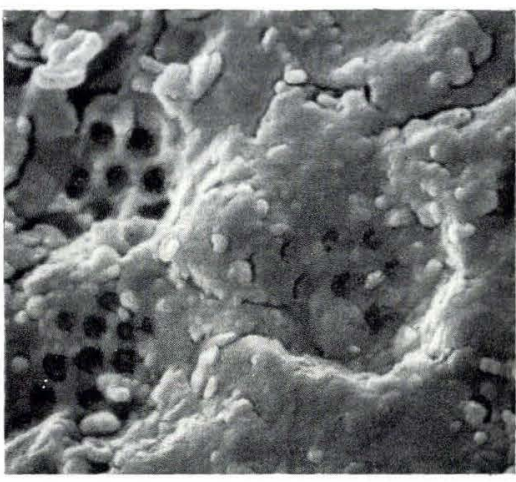

4

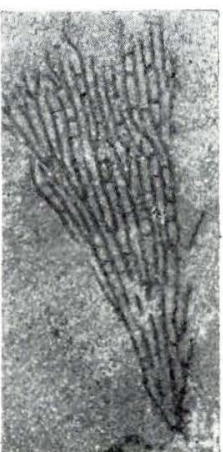

3 